\title{
Effect of Emergency Argon on FCF Operational Incidents
}

Charles Solbrig

December 2011

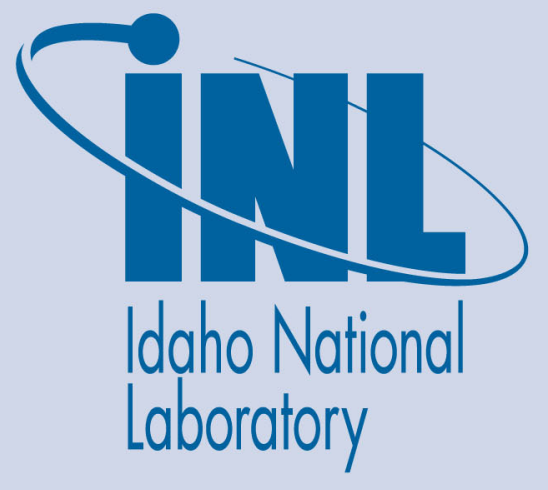

The INL is a U.S. Department of Energy National Laboratory operated by Battelle Energy Alliance 


\section{DISCLAIMER}

This information was prepared as an account of work sponsored by an agency of the U.S. Government. Neither the U.S. Government nor any agency thereof, nor any of their employees, makes any warranty, expressed or implied, or assumes any legal liability or responsibility for the accuracy, completeness, or usefulness, of any information, apparatus, product, or process disclosed, or represents that its use would not infringe privately owned rights. References herein to any specific commercial product, process, or service by trade name, trade mark, manufacturer, or otherwise, does not necessarily constitute or imply its endorsement, recommendation, or favoring by the U.S. Government or any agency thereof. The views and opinions of authors expressed herein do not necessarily state or reflect those of the U.S. Government or any agency thereof. 


\section{Effect of Emergency Argon on FCF Operational Incidents}

Charles Solbrig

December 2011

Idaho National Laboratory Idaho Falls, Idaho 83415

http://www.inl.gov

Prepared for the

U.S. Department of Energy

Office of Nuclear Operations

Under DOE Idaho Operations Office

Contract DE-AC07-05ID14517 
INL/EXT-11-21198

Revision 0

December 2011

\section{SUMMARY}

The following report presents analyses of operational incidents which are considered in the safety analysis of the FCF argon cell and the effect that the operability of the emergency argon system has on the course of these incidents. The purpose of this study is to determine if the emergency argon system makes a significant difference in ameliorating the course of these incidents.

Six incidents were considered. The following three incidents were analyzed:

1. Cooling failing on

2. Vacuum pump failing on

3. Argon supplies failing on.

In the remaining three incidents, the emergency argon supply would have no effect on the course of these transients since it would not come on during these incidents. The transients are:

1. Loss of cooling

2. Loss of power (differs from above by startup delay till the diesel generators come on)

3. Cell rupture due to an earthquake or other cause.

The analyses of the first three incidents are described in the next three sections.

This report is issued realizing the control parameters used may not be optimum, and additional modeling must be done to model the inertia of refrigeration system, but the major conclusion concerning the need for the emergency argon system is still valid. The timing of some events may change with a more accurate model, but the differences between the transients with and without emergency argon will remain the same.

Some of the parameters assumed in the analyses are:

Makeup argon supply, $18 \mathrm{cfm}$, initiates when pressure is $\leq-6$ iwg and shuts off when pressure is $\geq-3.1$ iwg with a capacity of $170,000 \mathrm{ft}^{3}$ supply. (min $1 / 7^{\text {th }}$ always available). The FCF argon supply system can be cross connected to HFEF argon supply dewar, which also has $179,000 \mathrm{ft}^{3}$. supply capacity

Emergency argon supply, $900 \mathrm{cfm}$, initiates when pressure is $\leq-8 \mathrm{iwg}$, shuts off when pressure is $\geq-4$ iwg, reservoir $2,200 \mathrm{ft}^{3}$.Ten $220 \mathrm{ft}^{3}$ gas cylinders are manually replaced when systempressure reduces to $1,050 \mathrm{psi}$, which is about $1,100 \mathrm{ft}^{3}$. 
INL/EXT-11-21198

Revision 0

December 2011

\section{CONTENTS}

SUMMARY

ACRONYMS

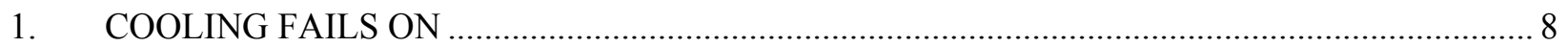

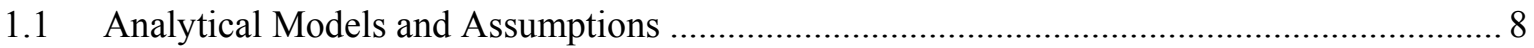

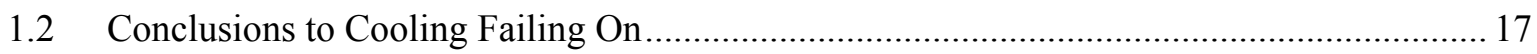

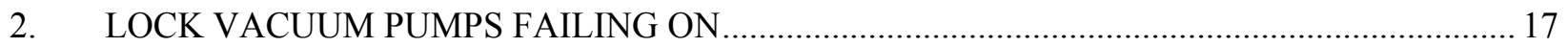

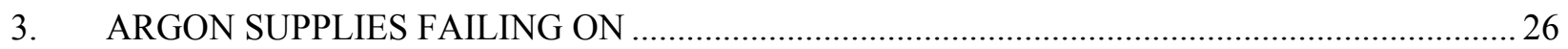

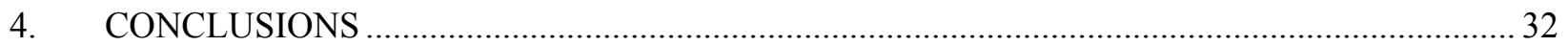

\section{FIGURES}

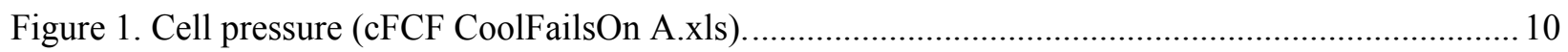

Figure 2. Cell temperature ((cFCF CoolFailsOn A.xls) ....................................................................... 10

Figure 3. Flow rates-semilog plot (cFCF CoolFailsOn A.xls) ............................................................. 11

Figure 4. Flow rates - Linear (cFCF CoolFailsOn A.xls) .................................................................... 11

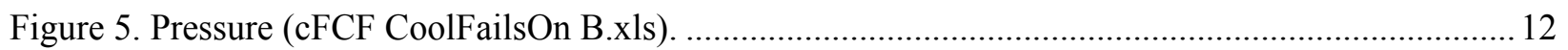

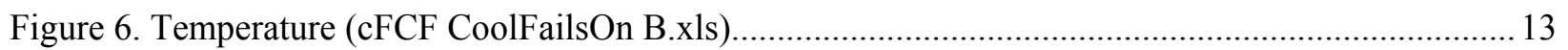

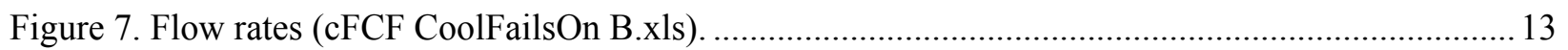

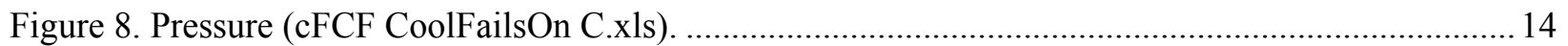

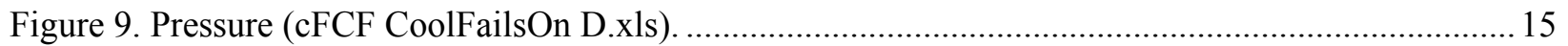

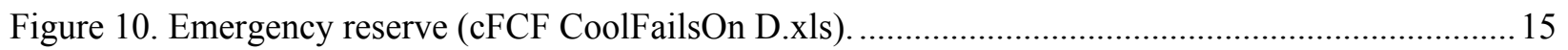

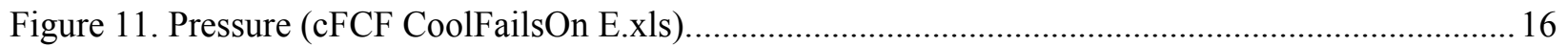

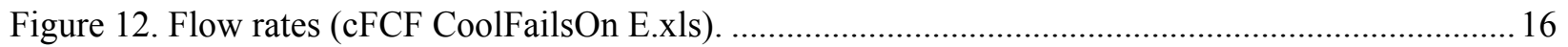

Figure 13. Pressure history (dFCF VacPumpFailsOn A-20 min limit.xls)............................................. 18

Figure 14. Temperatures (dFCF VacPumpFailsOn A-20 min limit.xls).................................................. 19

Figure 15. Flow rates (dFCF VacPumpFailsOn A-20 min limit.xls).................................................... 19

Figure 16. Energy contributions (dFCF VacPumpFailsOn A-20 min limit.xls).....................................20

Figure 17. Pressure history (dFCF VacPumpFailsOn B-20 min limit400cfm.xls)................................2 21

Figure 18. Pressure history - (dFCF VacPumpFailsOn C-20 min limit No emer.xls)............................22

Figure 19. Pressure history (dFCF VacPumpFailsOn D-No time limit.xls). ..........................................22

Figure 20. Temperatures (dFCF VacPumpFailsOn D-No time limit.xls) ...............................................2 
INL/EXT-11-21198

Revision 0

December 2011

Figure 21. Flow rates (dFCF VacPumpFailsOn D-No time limit.xls).................................................23

Figure 22. Pressure history (dFCF VacPumpFailsOn E-No time limit NoEmer.xls)..............................24

Figure 23. Temperatures (dFCF VacPumpFailsOn E-No time limit NoEmer.xls)...................................24

Figure 24. Flow rates (dFCF VacPumpFailsOn E-No time limit NoEmer.xls)....................................... 25

Figure 25. Mass (dFCF VacPumpFailsOn E-No time limit NoEmer.xls). ..............................................25

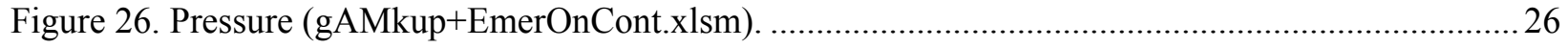

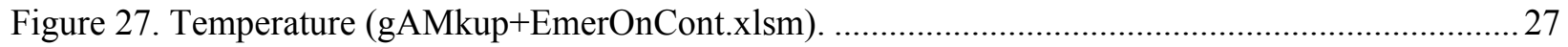

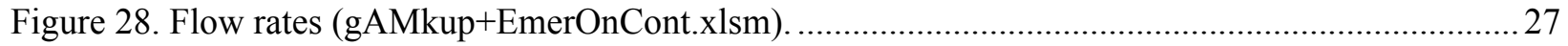

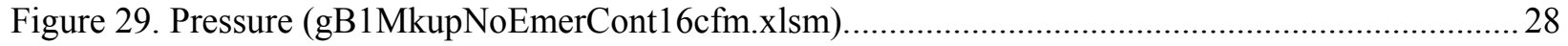

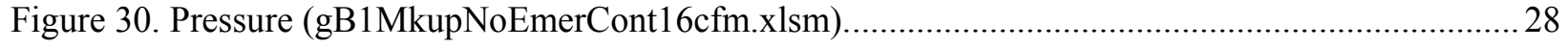

Figure 31. Temperature (gB1MkupNoEmerCont16cfm.xlsm) ….........................................................29

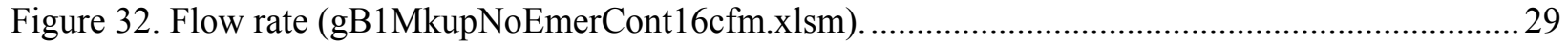

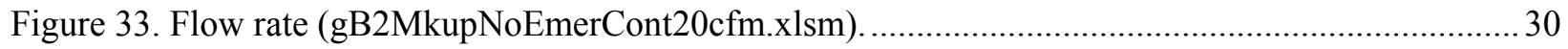

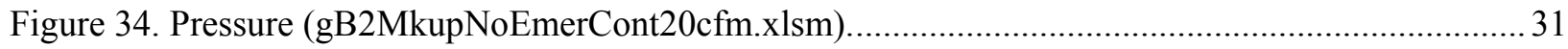

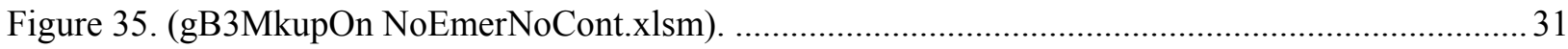

\section{TABLES}

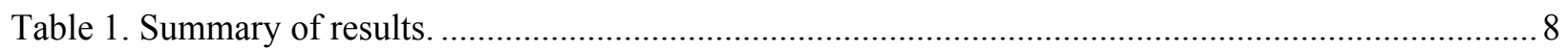

Table 2. Results summary of vacuum pump failing on study ............................................................ 17 
INL/EXT-11-21198

Revision 0

December 2011

\section{ACRONYMS}

$\begin{array}{ll}\text { PID } & \text { proportional integral derivative } \\ \text { P-PID } & \text { pressure-proportional integral derivative } \\ \text { T-PID } & \text { temperature-proportional integral derivative } \\ \text { FCF } & \text { Fuel Conditioning Facility } \\ \text { HFEF } & \text { Hot Fuel Examination Facility } \\ \text { SES } & \text { safety exhaust system } \\ \text { F/B } & \text { feed/bleed (system) } \\ \text { P } & \text { pressure (in the argon cell) } \\ \text { kW } & \text { kilowatt } \\ \text { iwg } & \text { inches water gauge pressure } \\ \text { cfm } & \text { cubic feet per minute }\end{array}$


INL/EXT-11-21198

Revision 0

December 2011

\section{Effect of Emergency Argon on FCF Operational Incidents}

\section{COOLING FAILS ON}

The cooling incident is caused by the refrigeration failing on. This could be caused by the failure of the pressure-proportional integral derivative (P-PID), which controls the cell pressure by changing the refrigeration. The P-PID controls only one loop, so the failure is assumed to be only one cooling loop failing on with a cooling potential of $-100 \mathrm{~kW}$ at normal cell temperature which decreases as the cell temperature decreases. A results summary of the "cooling fails on" incident is shown in Table 1 for different assumed operating conditions. The first four cases consider a range of heat generation levels in the cell and assume the emergency argon system is functioning. The fifth case analyses the largest heat generation and assumes the emergency argon system is not available. The models used in the analysis and the details of each incident are described following the table.

Table 1. Results summary of "cooling fails on" incident.

\begin{tabular}{|c|c|c|c|c|c|c|}
\hline & $\begin{array}{l}\text { Equipment, } \\
\text { Lights }\end{array}$ & Cooling & Emergency Argon & $\begin{array}{l}\text { Vacuum } \\
\text { Pumps }\end{array}$ & $\begin{array}{c}\text { Lowest } \\
\text { Pressure }\end{array}$ & $\begin{array}{l}\text { Conditions at } \\
1,000 \text { Minutes }\end{array}$ \\
\hline 1. & $\begin{array}{l}21 \mathrm{~kW} \\
25 \mathrm{~kW}\end{array}$ & $\begin{array}{l}-100 \mathrm{~kW} \\
\text { Net Cool } \\
-44.5 \mathrm{~kW}\end{array}$ & $\begin{array}{l}\text { Yes, but does not } \\
\text { come on }\end{array}$ & $16 \mathrm{cfm} \max$ & $-7.2 \mathrm{iwg}$ & $\begin{array}{l}\text { By } 400 \text { minutes makeup } \\
\text { keeps } \mathrm{P} \\
>-6 \&<-3.1 \mathrm{iwg}\end{array}$ \\
\hline 2. & $\begin{array}{l}0 \mathrm{~kW} \\
25 \mathrm{~kW}\end{array}$ & $\begin{array}{l}-100 \mathrm{~kW} \\
\text { Net Cool } \\
-65.5 \mathrm{~kW}\end{array}$ & $\begin{array}{l}\text { Yes, it comes on } \\
\text { once }\end{array}$ & $16 \mathrm{cfm} \max$ & $-8 \mathrm{iwg}$ & $\begin{array}{l}\text { By } 500 \text { minutes makeup } \\
\text { keeps P } \\
>-6 \&<-3.1 \mathrm{iwg}\end{array}$ \\
\hline 3. & $\begin{array}{l}0 \mathrm{~kW} \\
0 \mathrm{~kW}\end{array}$ & $\begin{array}{l}-100 \mathrm{~kW} \\
\text { Net Cool } \\
-85 \mathrm{~kW}\end{array}$ & $\begin{array}{l}\text { Yes, it comes on } \\
\text { twice }\end{array}$ & $16 \mathrm{cfm} \max$ & $-8 \mathrm{iwg}$ & $\begin{array}{l}\text { By } 705 \text { minutes makeup } \\
\text { keeps } \mathrm{P} \\
>-6 \text { \& }<-3.1 \text { iwg }\end{array}$ \\
\hline 4. & $\begin{array}{l}0 \mathrm{~kW} \\
0 \mathrm{~kW}\end{array}$ & $\begin{array}{l}-125 \mathrm{~kW} \\
\text { Net Cool } \\
-115 \mathrm{~kW}\end{array}$ & $\begin{array}{l}\text { Yes, it comes on } \\
\text { three times }\end{array}$ & $16 \mathrm{cfm}$ & $-8 \mathrm{iwg}$ & $\begin{array}{l}\text { By } 650 \text { minutes makeup } \\
\text { keeps P } \\
>-6 \&<-3.1 \text { iwg }\end{array}$ \\
\hline 5. & $\begin{array}{l}0 \mathrm{~kW} \\
0 \mathrm{~kW}\end{array}$ & $\begin{array}{l}-125 \mathrm{~kW} \\
\text { Net Cool } \\
-115 \mathrm{~kW} \\
\end{array}$ & No & $16 \mathrm{cfm}$ & -17 iwg & $\begin{array}{l}\text { Will return to }-3.1 \mathrm{iwg} \\
\text { after } \sim 2,000 \mathrm{~min}\end{array}$ \\
\hline
\end{tabular}

\subsection{Analytical Models and Assumptions}

In all cases, it is assumed that there is $15 \mathrm{~kW}$ of decay heat.

Feed/Bleed Vacuum Pumps: In the current mode of operation, the temperature temperatureproportional integral derivative (T-PID) will turn the small vacuum pumps on when the temperature decreases below the temperature setpoint. This T-PID action works well when the pressure setpoint is lowered for operational purposes, but it exacerbates this transient. There are four pumps which are rated at $5 \mathrm{cfm}$ each but currently provide 5,10 , or $16 \mathrm{cfm}$ (pump outlet manifold size restricts flow to $16 \mathrm{cfm}$ with four pumps running) depending upon the signal from the T-PID. The number of pumps operating depends upon how far the temperature is below the temperature setpoint. The lower the temperature, the more pumps that come on, and it is either 1,2 , or 4 pumps. 
INL/EXT-11-21198

Revision 0

December 2011

Argon Flow: In each of these runs, the makeup argon flow rate was assumed to be the rated $18 \mathrm{cfm}$. It is unlikely that this flow would degrade. In addition, there is a cover gas feed into the electrorefiner and other equipment that totals about $2 \mathrm{cfm}$. The negative $16 \mathrm{cfm}$ from the feed/bleed (F/B) pumps plus the positive input from the covergas results in a negative $14 \mathrm{cfm}$ which turns to a positive $4 \mathrm{cfm}$ when the makeup argon comes on. As long as a net positive argon flow occurs, the pressure would eventually return to normal rather than continuing down to the underpressure relief.

Five different cases were run. Four different net cooling rates were investigated in these cases. The net excess cooling rate of $-44.45 \mathrm{~kW}$ in the first case is the most likely condition for this incident. Progressively larger cooling rates were investigated in the next three cases. Finally, in the fifth case, the effect of the failure of the emergency argon supply with the largest cooling rate of case 4 was investigated.

Cooling Rates: There are two cooling loops in FCF. Each is assumed to be capable of supplying $100 \mathrm{~kW}$ of cooling. The P-PID controls only one loop at a time. The P-PID is assumed to fail causing the controlled loop to fail on. The other loop is in manual control. In the first case, there is $21 \mathrm{~kW}$ of equipment residual heat, $25 \mathrm{~kW}$ of heat from lights, plus $15 \mathrm{~kW}$ of decay heat. Two thirds of the light heat goes directly to the cell; the other third goes radiantly to the walls. At steady state about $3 / 4$ of the energy to the wall goes to the outside, and $1 / 4$ or about $2 \mathrm{~kW}$ comes back to the cell by convection. (Note, the cell walls are at a higher temperature than the cell.) So the total cell heat load is $55.55 \mathrm{~kW}$. With the failed on cooling loop, this results in a net cooling rate of $-44.45 \mathrm{~kW}$, at the initiation of the incident. In the second case, all the lights and equipment are assumed to be off at the initiation of the incident. In the third case, the equipment and the lights are off making the initial cooling rate $-85 \mathrm{~kW}$. The fourth case considers $-115 \mathrm{~kW}$ of excess cooling capacity, where one loop has been manually controlled to balance the decay heat in the cell and the other loop fails on. The fifth case is the same as the fourth, but the emergency argon is assumed to be off as well.

The capacity of the refrigeration is assumed to be a maximum at a temperature of $95^{\circ} \mathrm{F}$ and to decrease linearly as the temperature of the cell decreases, with a zero capacity assumed at the refrigeration supply temperature to the cell of $20^{\circ} \mathrm{F}$. Thus the power removed from the cell is modeled as:

$$
\begin{gathered}
\mathrm{Q}_{\text {fridg }}=-100 \mathrm{~kW} \frac{\left(\mathrm{T}_{\text {Cell }}-\mathrm{T}_{\text {sink }}\right)}{\left(\mathrm{T}_{\text {MaxFridg }}-\mathrm{T}_{\text {sink }}\right)} \\
\text { where } \mathrm{T}_{\text {MaxFridg }}=95^{\circ} \mathrm{F}, 35^{\circ} \mathrm{C} \\
\mathrm{T}_{\text {sink }}=20^{\circ} \mathrm{F},-6.7^{\circ} \mathrm{C}
\end{gathered}
$$

\section{A. Lights 25 kW, Equip 21 kW, Vacuum Pumps 16 cfm, Emergency Argon}

The net excess cooling that occurs to start this incident is $44.45 \mathrm{~kW}$ which is the sum of the $100 \mathrm{~kW}$ refrigeration, the lights, the equipment, and the decay heat. As soon as the temperature starts to decrease, the vacuum pumps start to cascade on. The pressure is shown in Figure 1. The maximum F/B vacuum pump flow is assumed to be $16 \mathrm{cfm}$ flow. This maximum flow can be turned on by the T-PID when the temperature from the overcooling gets low enough. The pressure decreases initially due to the cooling and the F/B vacuum pumps. The $18 \mathrm{cfm}$ makeup comes on at -6 iwg. Its effect on the pressure is not noticeable at that time, but it is able to turn the pressure around when it decreases to $-7.2 \mathrm{iwg}$. The pressure increases to the $-3.1 \mathrm{iwg}$ setpoint of the makeup argon at which time it shuts off. The vacuum pumps continue to run due to the low temperature, and the pressure starts down again until it again reaches -6 iwg. This time the makeup is able to turn the pressure around immediately. The pressure then oscillates on and off with a period of 200 minutes. 
INL/EXT-11-21198

Revision 0

December 2011

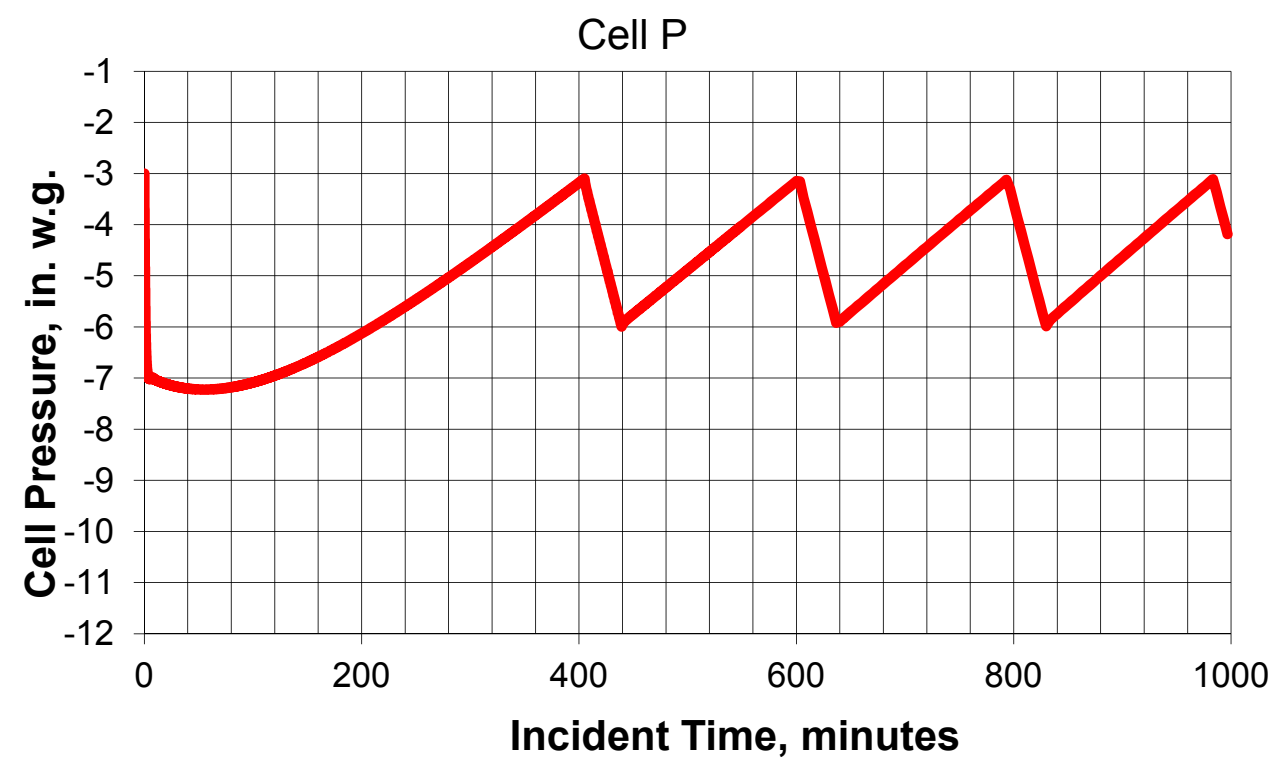

Figure 1. Cell pressure (cFCF CoolFailsOn A.xls).

The temperature is shown in Figure 2. The temperature decreases quickly from the operating temperature of 30.4 to $26.5^{\circ} \mathrm{C}$, at which time the temperature difference between the gas and the wall come to equilibrium with the increased cooling load. Then the temperature continues on down at a slower rate as the walls cool down. The temperature difference between the walls and the gas remain almost constant after the initial sharp drop in temperature.

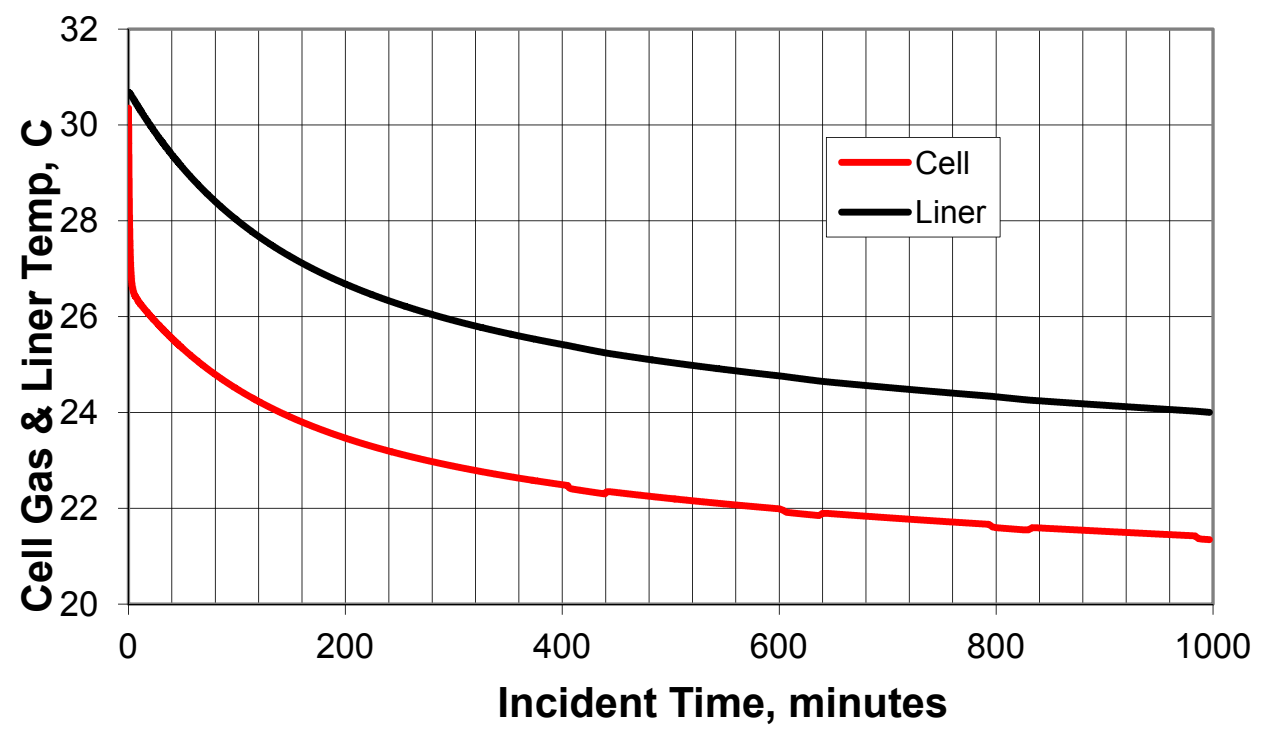

Figure 2. Cell temperature ((cFCF CoolFailsOn A.xls).

The flow rates are shown in Figure 3 in a semilog scale. The cover gas flow of $2 \mathrm{cfm}$ is constantly on. The makeup argon supply comes on a little over one minute after initiation of the transient due to the decrease in pressure to -6 iwg. The first F/B vacuum pump activates at 24 seconds, the second at 3.5 
INL/EXT-11-21198

Revision 0

December 2011

minutes, and the third and fourth at eight minutes. The makeup supply turns off when the pressure has increased to its set point. This is shown in Figure 3 and Figure 4.

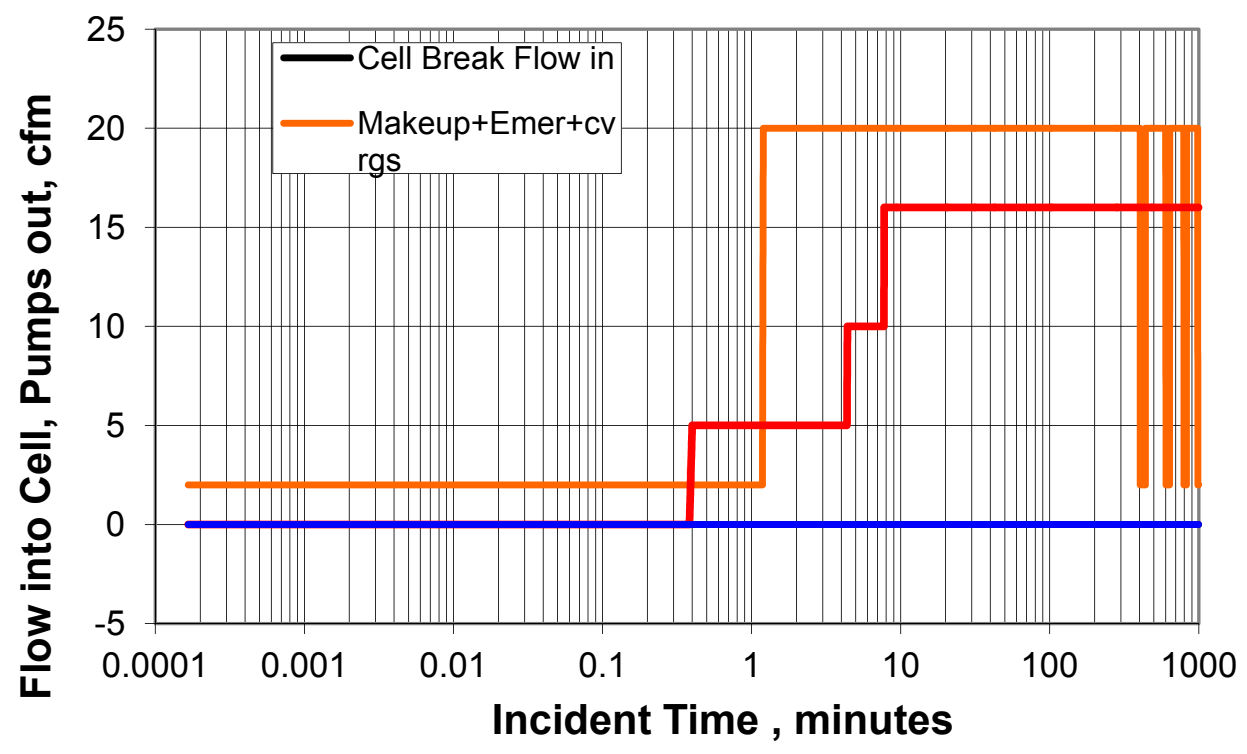

Figure 3. Flow rates-semilog plot (cFCF CoolFailsOn A.xls).

The linear scale in Figure 4 shows that the makeup flow shuts off at 405 minutes leaving only the $2 \mathrm{cfm}$ cover gas. It turns back on again when the pressure is brought down again with the vacuum pump flow. The period of on and off flow becomes almost constant from that time on. The operators will shut off the vacuum pumps if the refrigeration repair cannot be affected quickly.

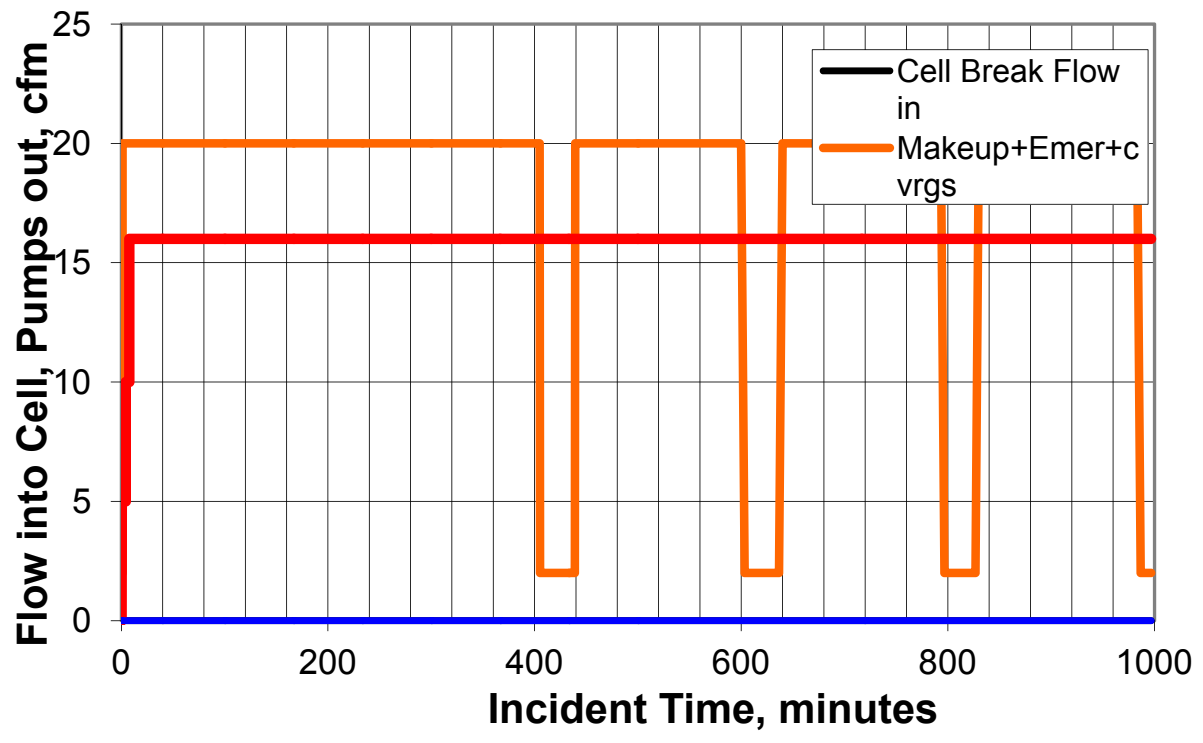

Figure 4. Flow rates - Linear (cFCF CoolFailsOn A.xls). 
INL/EXT-11-21198

Revision 0

December 2011

The tank of liquid argon supplying the makeup argon contains $170,000 \mathrm{ft}^{3}$ at full capacity. There is always at least $1 / 7^{\text {th }}$ of this in the tank or about $24,000 \mathrm{ft}^{3}$. This transient used up about $18,000 \mathrm{ft}^{3}$ by 1,000 minutes due to low temperature and the T-PID causing the F/B vacuum pumps continuing to remove cell gas in this transient. There is also a cross connect to the tank at Hot Fuel Examination Facility (HFEF) which can continue to supply makeup argon if needed.

This is perhaps the most realistic case studied, although the amount of excess cooling may be somewhat low because the actual heat generation in the cell during normal operation may be less than that assumed in this case. The makeup argon keeps the pressure above the emergency argon setpoint for the duration of this calculated transient, which is 1,000 minutes ( 16 hours). The operators will be able return the refrigeration to normal operation or turn off the vacuum pumps, which would allow the pressure to come back to the normal operating pressure probably much faster than the 16 hours.

\section{B. Lights 25 kW, Equip 0 kW, Vacuum Pumps 16 cfm, Emergency Argon}

This incident has the same conditions as Section A except that there is no equipment heat, so the total heat to the cell is $34.55 \mathrm{~kW}$, and the net excess cooling when the $100 \mathrm{~kW}$ of refrigeration fails on is $65.45 \mathrm{~kW}$. A direct comparison to the previous case can be made by comparing Figure 5 to Figure 1 . The pressure does decrease to the emergency argon setpoint of -8 iwg, and this supply brings the pressure up to its shut off setpoint of $-4 \mathrm{iwg}$. The emergency argon supply has not been exhausted, but it does not come back on. The makeup argon is able to keep the pressure between its setpoints of -6 and -3.1 iwg for the remainder of the 1,000 minute time period. Although not accurately shown in the semilog plot in Figure 5, the oscillatory behavior is the same as shown in Figure 1 with an on off period of 200 minutes.

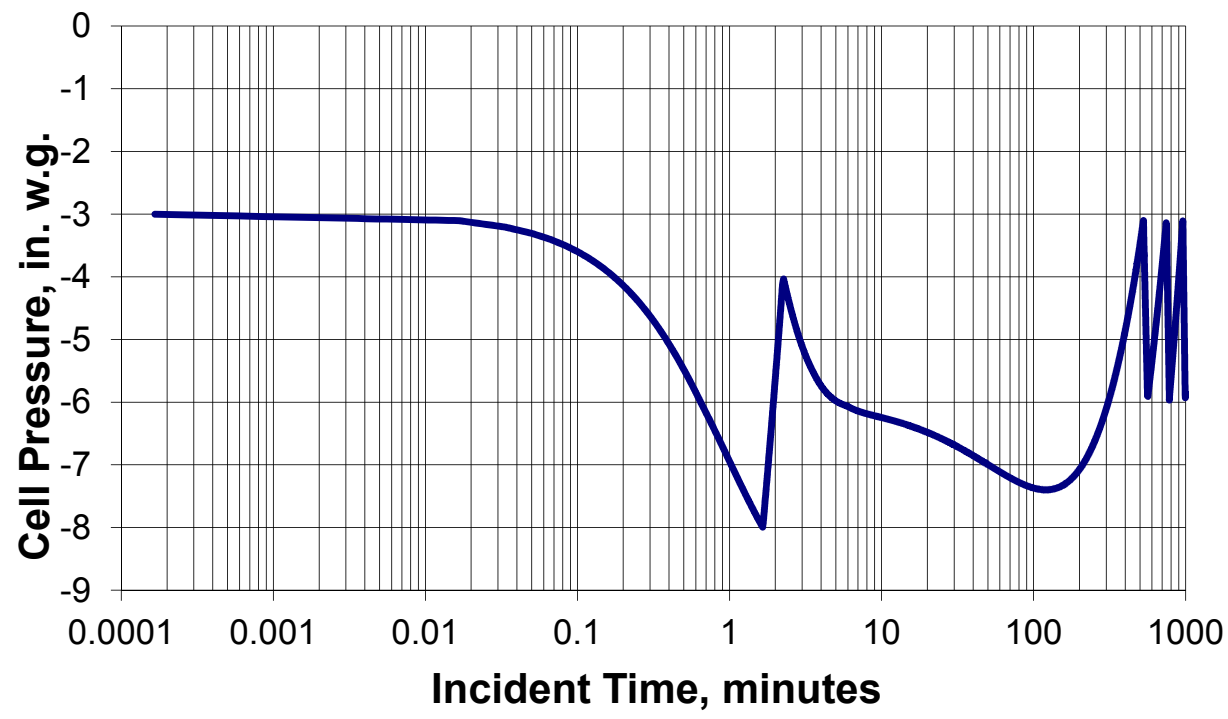

Figure 5. Pressure (cFCF CoolFailsOn B.xls). 
INL/EXT-11-21198

Revision 0

December 2011

The cell temperatures are shown in Figure 6. The cell gas temperature is lower because of the larger excess cooling in the cell in this incident.

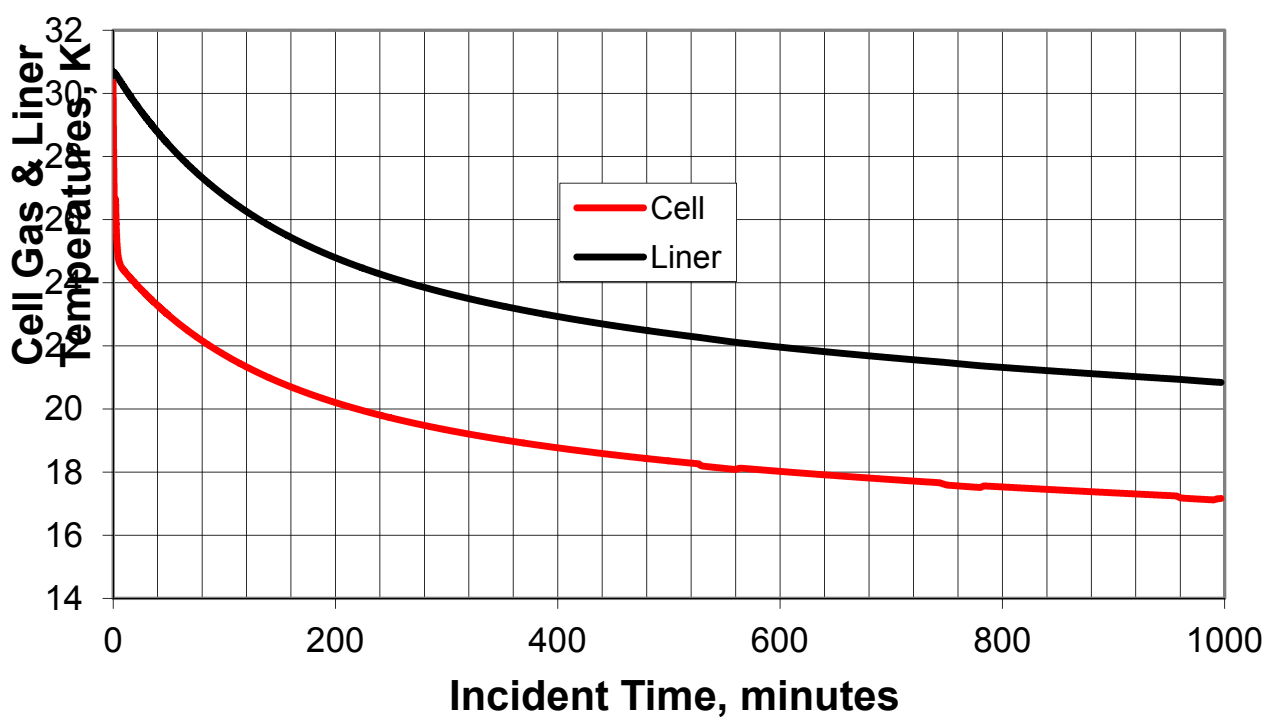

Figure 6. Temperature (cFCF CoolFailsOn B.xls).

The flow is shown in Figure 7. The contribution of the $900 \mathrm{cfm}$ emergency supply has been cropped (the supply is $920 \mathrm{cfm}$ from 1.8 to $2.2 \mathrm{~min}$ ) so that the behavior of the other supplies and the vacuum pumps can be seen. It is noted that once the vacuum pumps come on, they remain on as in Case A.

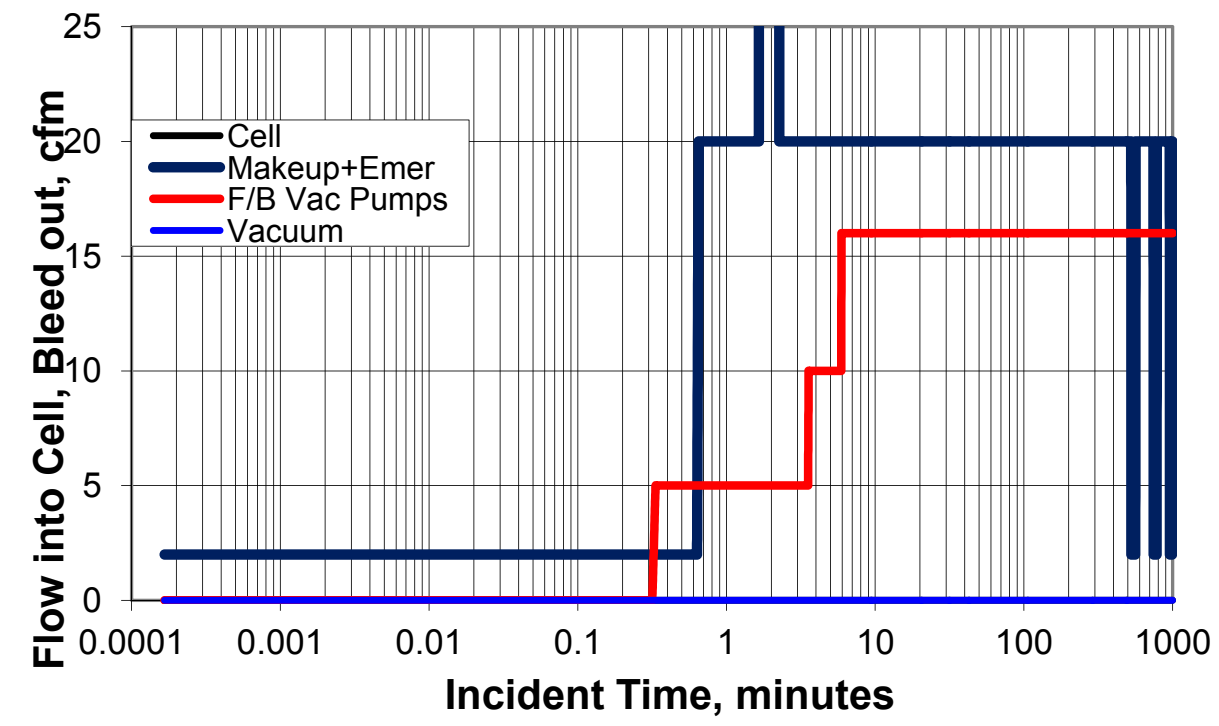

Figure 7. Flow rates (cFCF CoolFailsOn B.xls). 
INL/EXT-11-21198

Revision 0

December 2011

\section{Lights 0 kW, Equip 0 kW, Vacuum Pumps 16 cfm, Emergency Argon}

The pressure history of this incident, with $85.0 \mathrm{~kW}$ of excess cooling failing on, is shown in Figure 8 . The equipment and the lights are assumed to be off making the initial cooling rate $=-100 \mathrm{~kW}+15 \mathrm{~kW}=$ $-85 \mathrm{~kW}$. The pressure decreases more rapidly than in case A or B due to the additional cooling. The emergency argon comes on twice during this incident, when the pressure is brought down to its initiation setpoint and is able to bring the pressure up to -4 iwg both times, the second time more quickly. The third time that it decreases, it does not quite turn the emergency supply on, and the makeup is able to turn it around because of decreased cooling due to the degradation of the refrigeration system. The makeup argon brings the pressure up to $-3.1 \mathrm{iwg}$, and then the pressure continues to oscillate between the makeup argon supply setpoints.

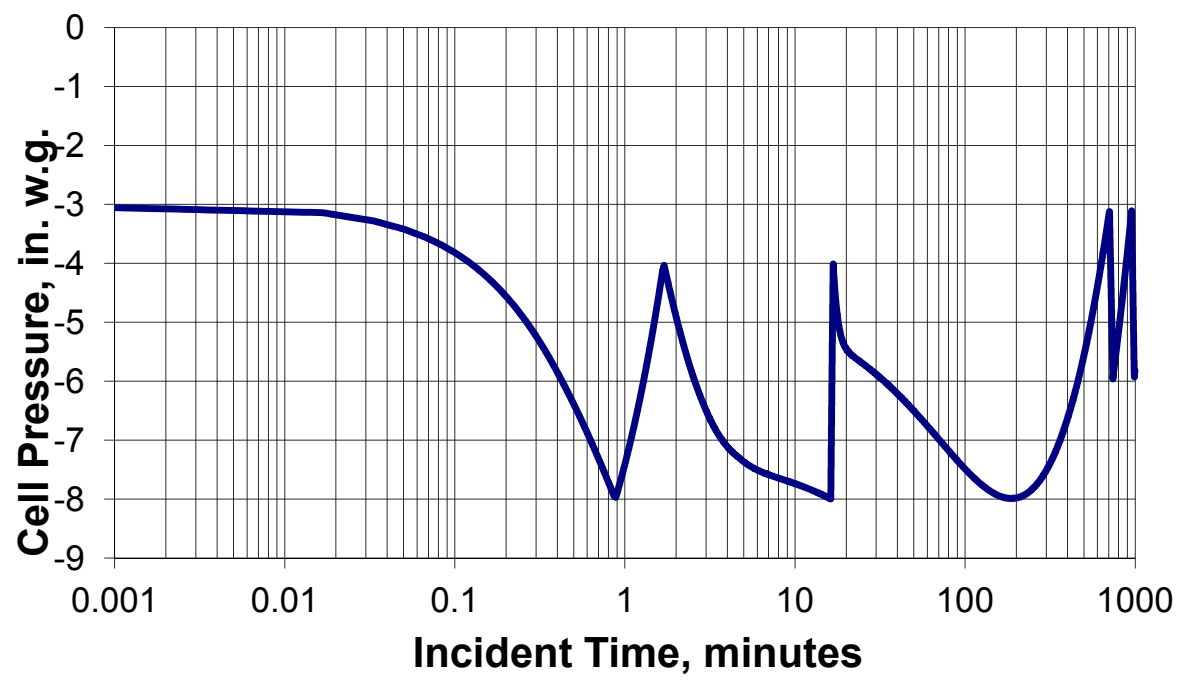

Figure 8. Pressure (cFCF CoolFailsOn C.xls).

The amount of argon used up in each of the above three cases is about the same. The total amount in the emergency supply is $2,200 \mathrm{ft}^{3}$, which is small compared to the $170,000 \mathrm{ft}^{3}$ supply for the makeup and cover gas. This case used $18,700 \mathrm{ft}^{3}$ of the makeup supply and $1,300 \mathrm{ft}^{3}$ of the emergency for a total of $20,000 \mathrm{ft}^{3}$.

\section{Excess Cooling of $-100 \mathrm{~kW}$, Vacuum Pumps $16 \mathrm{cfm}$, Emergency Argon}

This case considers $-115 \mathrm{~kW}$ of cooling capacity where one loop has been manually controlled to balance the $15 \mathrm{~kW}$ decay heat in the cell and the other loop fails on. The pressure history is shown in Figure 9. The emergency argon is shown to come on three times, as evidenced by the quick pressure increase to -4 iwg after the -8 iwg is reached. In this case, the makeup argon supply is actually able to keep the pressure in its range earlier than in Case C, probably because the emergency supply has put more argon in the cell. 
INL/EXT-11-21198

Revision 0

December 2011

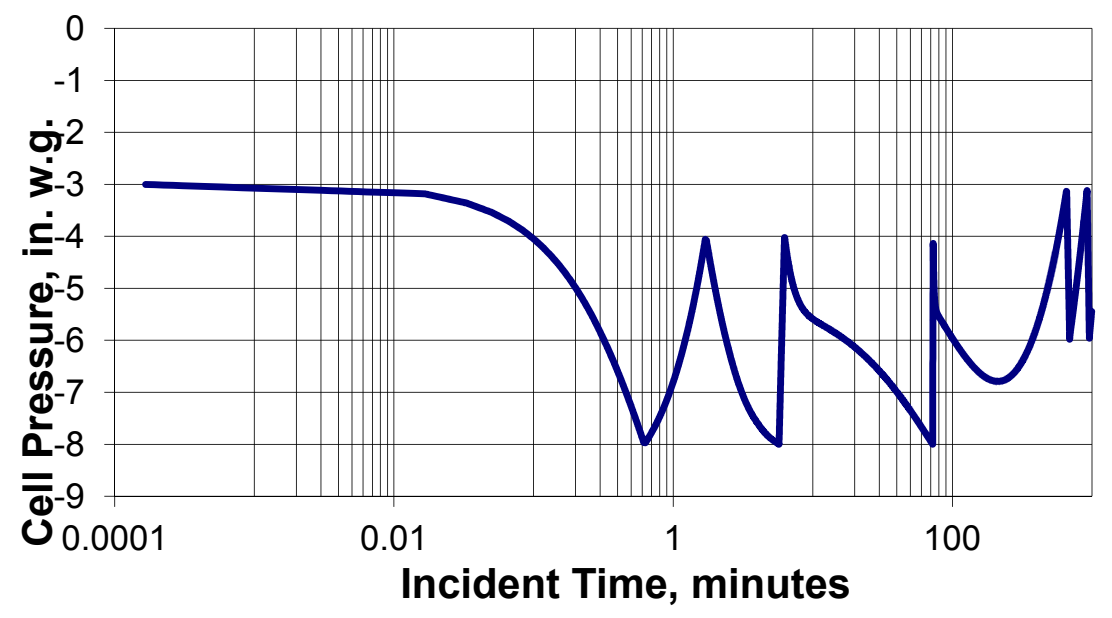

Figure 9. Pressure (cFCF CoolFailsOn D.xls).

The amount of argon in the emergency reserve is shown in Figure 10. It is seen that the reserve is not depleted at the end of the incident.

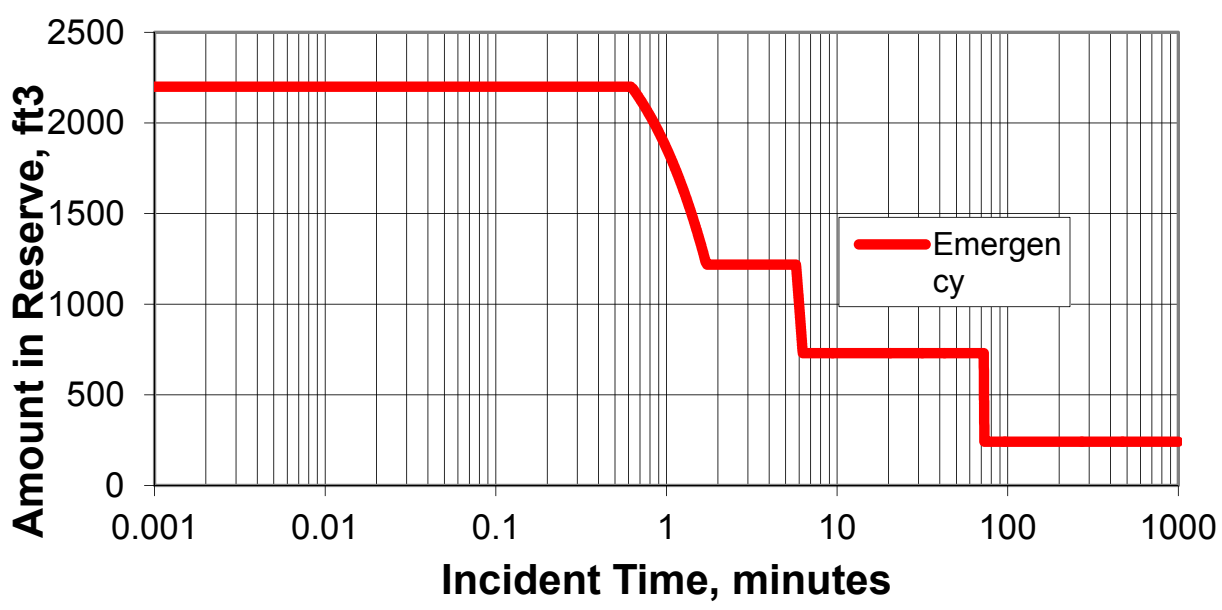

Figure 10. Emergency reserve (cFCF CoolFailsOn D.xls).

If the emergency argon supply were at its low pressure limit of $1,050 \mathrm{psi}$ at the beginning of this incident, the initial argon supply for the emergency argon would be about half of the value shown above and would empty at six minutes into the transient at the second drop.

\section{E. Excess Cooling -100 kW, Vacuum Pumps 16 cfm, No Emergency Argon}

The maximum excess cooling incident of $-100 \mathrm{~kW}$ excess cooling was rerun to determine the effects of the emergency argon being out of service when the incident proceeds. The pressure history is shown in Figure 11. It is seen that the pressure decreases to almost -17 iwg before the makeup argon is able to cause it to increase again. The pressure reaches the range where the makeup oscillates on and off starting at about 1,200 minutes. Even though there is no emergency argon, the pressure does not decrease to the underpressure relief setpoint, so no air comes in the cell even with this large excess cooling capacity. This is the largest excess cooling capacity considered possible from an unintended incident. 
INL/EXT-11-21198

Revision 0

December 2011

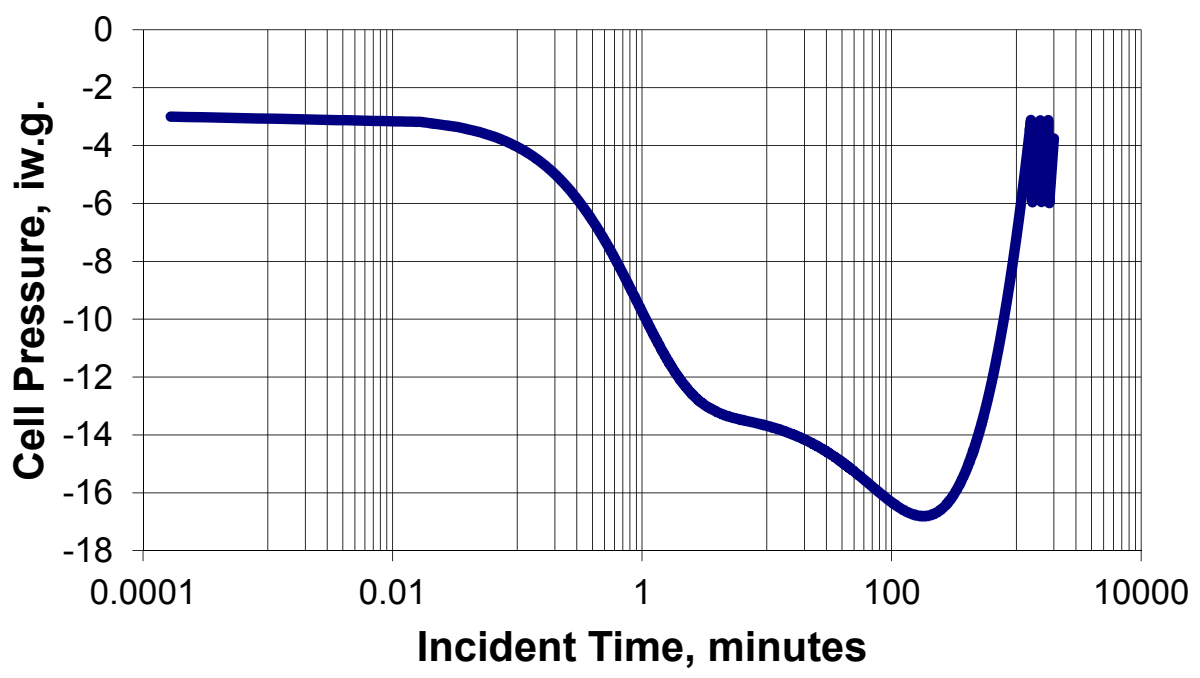

Figure 11. Pressure (cFCF CoolFailsOn E.xls).

The flow rates are shown in Figure 12. The makeup flow comes on at about 18 seconds, and the vacuum pumps start to cascade on a few seconds before. Both the makeup and the vacuum pumps remain on for the entire transient time, but the operators would shut off the vacuum pumps. Whether they do or not, the cell pressure will increase to the makeup shut off setpoint and then oscillate on and off after that. Since no emergency argon was supplied to the cell, approximately $20,000 \mathrm{ft}^{3}$ of argon is used in 1,000 minutes and $38,000 \mathrm{ft}^{3}$ of argon is used in 2,000 minutes.

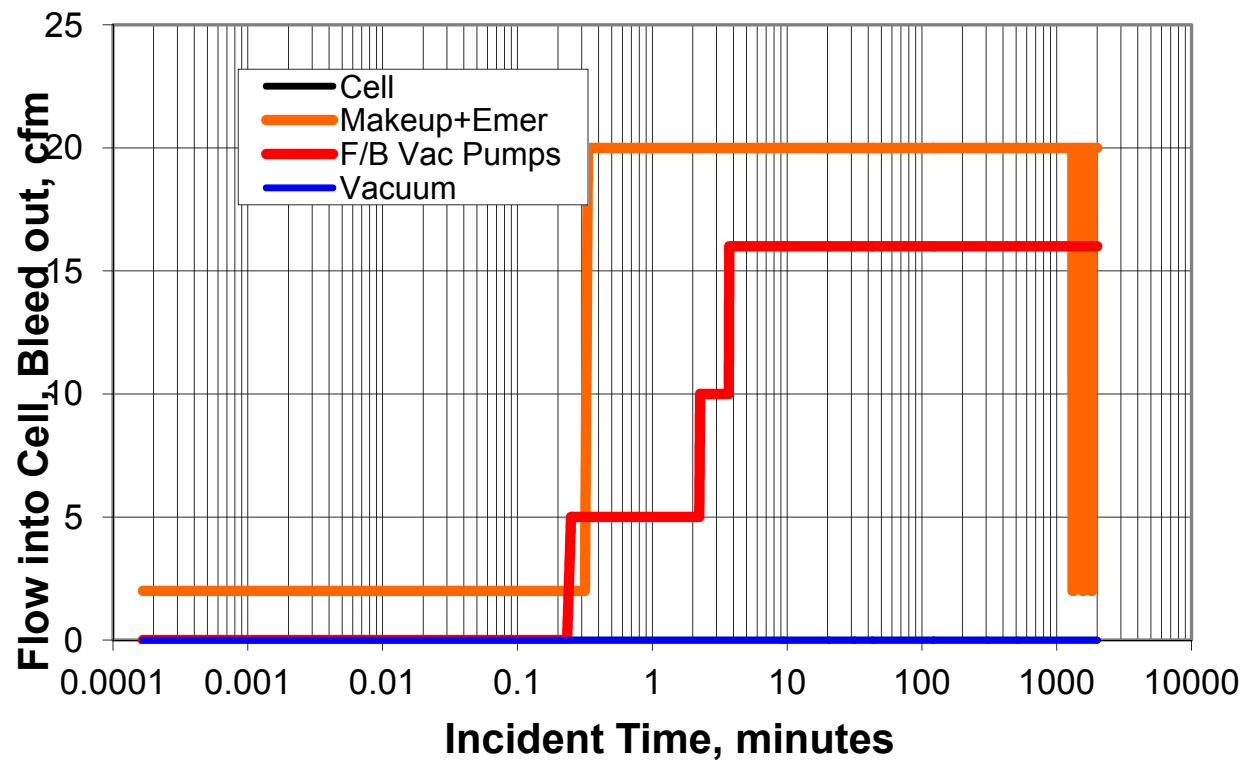

Figure 12. Flow rates (cFCF CoolFailsOn E.xls). 
INL/EXT-11-21198

Revision 0

December 2011

\subsection{Conclusions to Cooling Failing On}

The cell cooling failing on incident reduces the cell pressure and temperature. Even the largest excess cooling rate analyzed does not cause the under pressure relief to open. Even without the emergency argon, the pressure only decreases to $-17 \mathrm{iwg}$, and the makeup argon and covergas would eventually be able to bring the pressure back up to oscillate in the -3.1 to -6 iwg range, so the emergency argon is not necessary to resolve this incident.

\section{LOCK VACUUM PUMPS FAILING ON}

This section reports the analysis results of the lock vacuum pumps failing on incident with the inside lock door interlock disabled and the door open. The effects of three parameters were investigated including a time-out feature on the vacuum pump running time, the flow rate of the emergency argon supply, and the total absence of the emergency argon supply. The details are included in this report, and they are summarized in Table 2 . The vacuum time out feature is the most important feature. With it, the pressure never goes below -8 iwg during the transient, and the pressure will return to normal operating pressure in 42 minutes as long as the emergency argon flow (normally $900 \mathrm{cfm}$ ) is $140 \mathrm{cfm}$ or more. Without emergency argon flow, the pressure goes as low as -17 iwg but still returns to normal within 155 minutes.

Table 2. Results summary of vacuum pump failing on study.

\begin{tabular}{|c|c|c|c|c|}
\hline Vacuum Pump (140 cfm) & $\begin{array}{l}\text { Makeup } \\
\text { Argon }\end{array}$ & Emergency Argon & $\begin{array}{l}\text { Minimum } \\
\text { Pressure }\end{array}$ & Long Term \\
\hline A. Times out after $20 \mathrm{~min}$. & $\begin{array}{l}\text { On - } 6 \text { iwg } \\
\text { Off }-3.1 \text { iwg }\end{array}$ & $\begin{array}{l}\text { On }-8 \text { iwg, } \\
\text { Off }-4 \text { iwg, } 900 \mathrm{cfm}\end{array}$ & -8 iwg & $\begin{array}{l}\text { Pressure returns to } \\
\text { normal in } 42 \mathrm{~min} .\end{array}$ \\
\hline B. Times out after $20 \mathrm{~min}$. & $\begin{array}{l}\text { On - } 6 \text { iwg } \\
\text { Off }-3.1 \text { iwg }\end{array}$ & $\begin{array}{l}\text { On }-8 \text { iwg, } \\
\text { Off }-4 \text { iwg, } 400 \mathrm{cfm}\end{array}$ & $-8 \mathrm{iwg}$ & $\begin{array}{l}\text { Pressure returns to } \\
\text { normal in } 42 \mathrm{~min} .\end{array}$ \\
\hline C. Times out after $20 \mathrm{~min}$. & $\begin{array}{l}\text { On -6 iwg } \\
\text { Off }-3.1 \mathrm{iwg}\end{array}$ & No emergency flow & -17 iwg & $\begin{array}{l}\text { Pressure returns to } \\
\text { normal in } 155 \mathrm{~min} .\end{array}$ \\
\hline D. Continues to run & On - 6 iwg & On -8 iwg, $900 \mathrm{cfm}$ & $\begin{array}{l}\text { Under pressure } \\
\text { relief (-20 iwg) }\end{array}$ & $\begin{array}{l}\text { Combustion in } \\
150 \text { min. }\end{array}$ \\
\hline E. Continues to run & On - 6 iwg & No emergency flow & $\begin{array}{l}\text { Under pressure } \\
\text { relief }(-20 \text { iwg) }\end{array}$ & $\begin{array}{l}\text { Combustion in } \\
130 \text { min. }\end{array}$ \\
\hline
\end{tabular}

In two cases with no time out on the vacuum pump, the pressure will decrease to -20 iwg which opens the underpressure relief. Enough air flows into the cell to reach the $4 \%$ oxygen combustion limit. With the emergency argon system, the operators had 150 minutes to recover before combustion occurred. Without it, they still had 130 minutes. (Note, the actual underpressure relief is -21 iwg which would delay the beginning of combustion by two or three minutes in each case). 
INL/EXT-11-21198

Revision 0

December 2011

\section{A. Vacuum Pump Fails On - Times out in 20 Minutes - Emergency Argon $900 \mathrm{cfm}$}

The pressure history for a transient where a140 cfm lock vacuum pump fails on is shown in

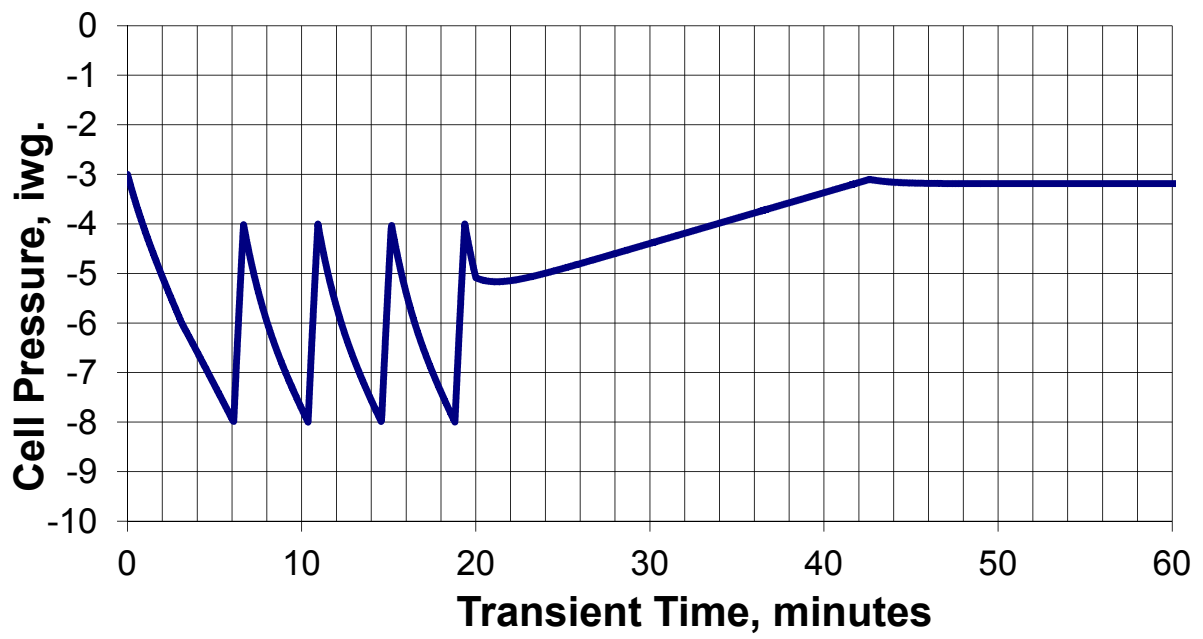

Figure 13. In this case, the makeup argon and the emergency argon supplies are assumed to operate as designed. The pressure declines to the -6 iwg setpoint of the $18 \mathrm{cfm}$ makeup supply and it turns on but the effect on the pressure trace is barely noticeable. The $900 \mathrm{cfm}$ rated emergency supply turns on at $-8 \mathrm{iwg}$ and brings the pressure back up to its -4 iwg shutoff setpoint in less than a minute. The pressure is brought down again over four minutes to the emergency supply setpoint and the process repeats until the vacuum pump times out at 20 minutes into the transient. Then the $18 \mathrm{cfm}$ makeup supply turns the pressure around and continues to bring the pressure up until its shutoff setpoint of -3.1 iwg is reached. Although the emergency argon flow rate in is $900 \mathrm{cfm}$, it only averages $140 \mathrm{cfm}$ to keep up with the $140 \mathrm{cfm}$ vacuum pump flow rate.

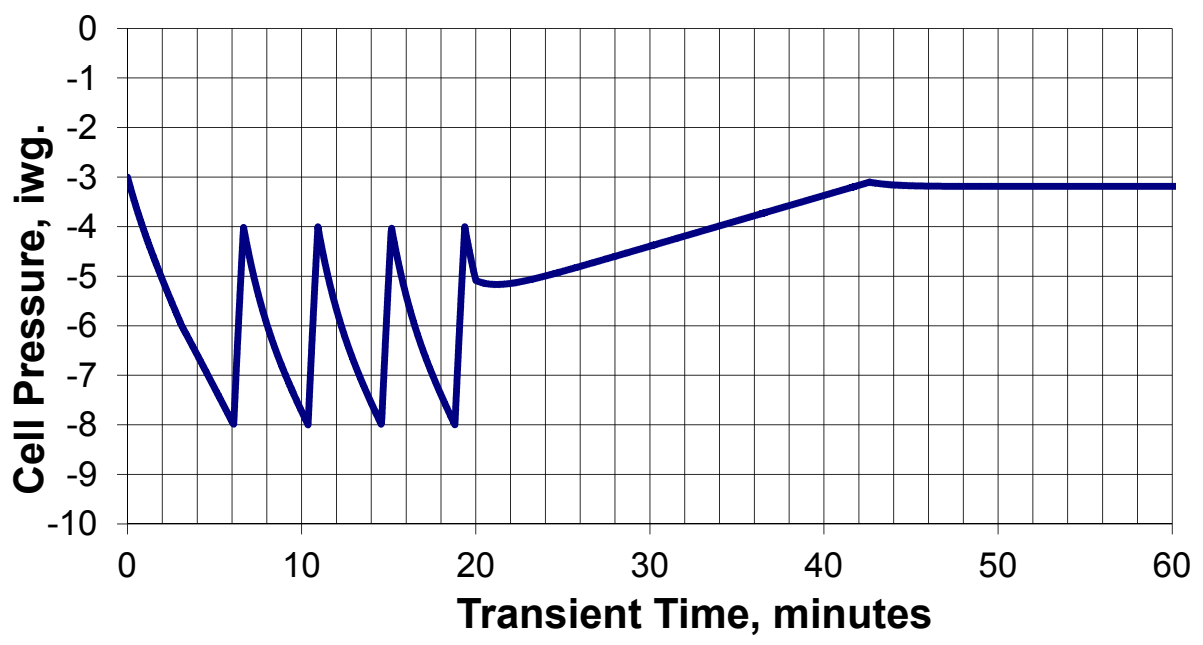

Figure 13. Pressure history (dFCF VacPumpFailsOn A-20 min limit.xls). 
INL/EXT-11-21198

Revision 0

December 2011

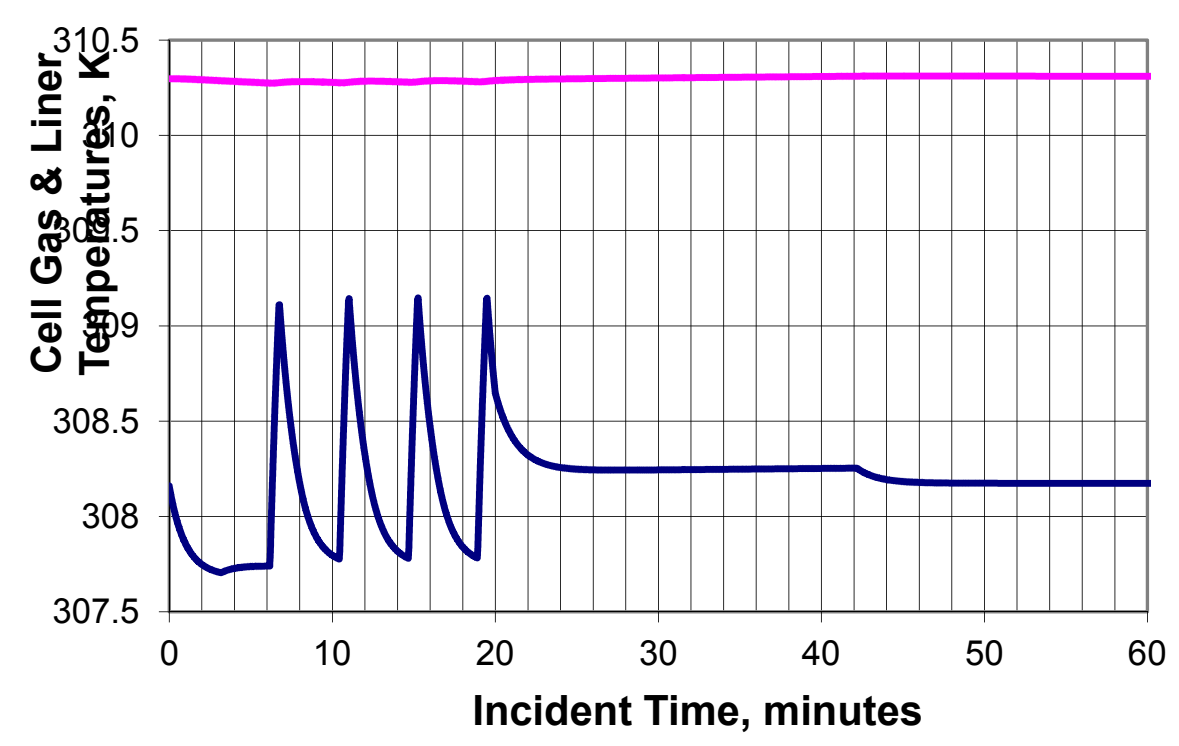

Figure 14. Temperatures (dFCF VacPumpFailsOn A-20 min limit.xls).

The cell temperature is shown in Figure 14. The small temperature fluctuations are due to the adiabatic compression and expansion caused by the flow into and out of the cell.

The flow rates are shown in Figure 15. The makeup and emergency argon flow rates are combined. The emergency flow is on for very short time periods and was not completely depleted with $7.4 \%$ of the original 2,200 $\mathrm{ft}^{3}$ remaining when the pump stops. The makeup supply turns off at 42 minutes when the pressure reaches $-3.1 \mathrm{iwg}$. The emergency argon supply can be less than the $2,200 \mathrm{ft}^{3}$ since the low pressure level for the emergency argon supply is 1,050 psig, so the actual argon supply in the tanks could be about half of that. In Case $\mathrm{C}$, presented later in this section, this problem was rerun assuming there was no emergency argon supply. In that case, the lowest pressure reached was -17 iwg and the underpressure relief does not open. So it follows that if the emergency supply is only $1,100 \mathrm{ft}^{3}$, then the lowest pressure reached will be $-17 \mathrm{iwg}$, and the underpressure relief will not open.

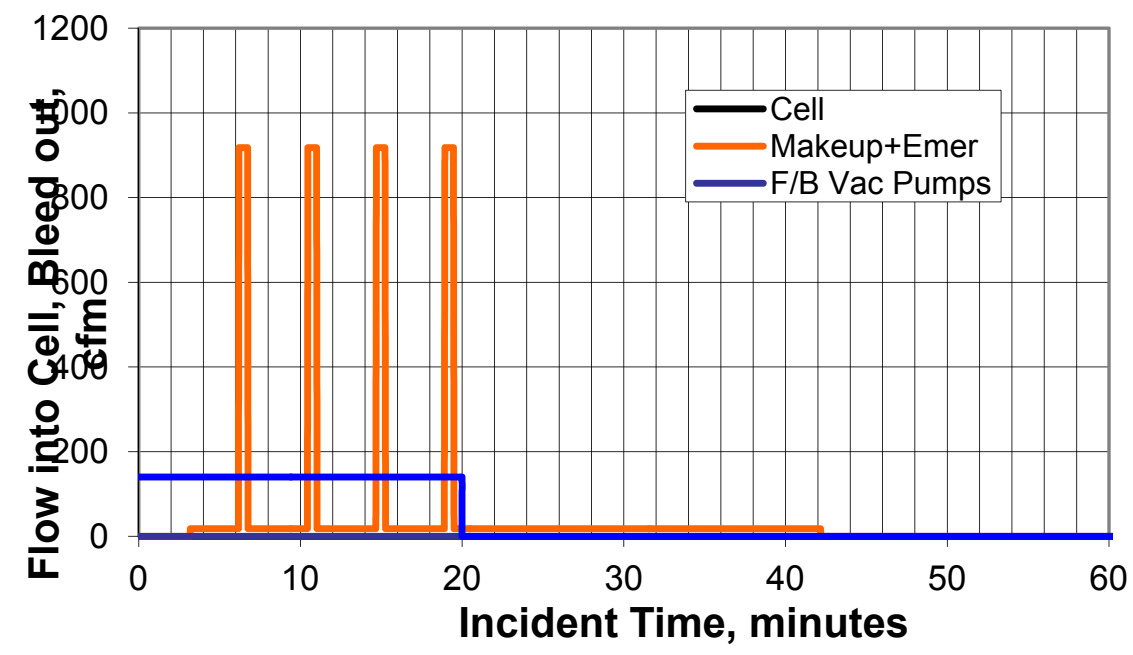

Figure 15. Flow rates (dFCF VacPumpFailsOn A-20 min limit.xls). 
INL/EXT-11-21198

Revision 0

December 2011

The contributions to the energy equation are shown in Figure 16. The lights have been assumed to remain on for this transient. In fact, the heat generation remains the same through incident initiation.

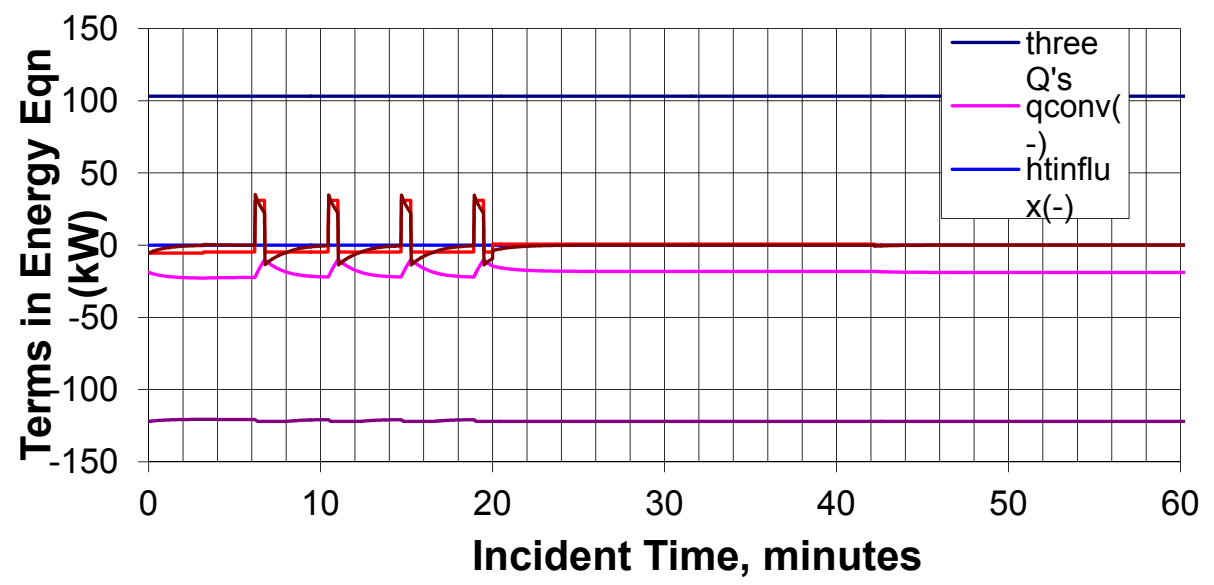

Figure 16. Energy contributions (dFCF VacPumpFailsOn A-20 min limit.xls).

In summary, the emergency argon supply does limit the negative pressure in the cell by keeping the pressure at or above -8 iwg.

\section{B. Vacuum Pump Fails On - Times out in 20 Minutes - Emergency Argon 400 cfm}

The pressure history for a140 $\mathrm{cfm}$ vacuum pump failing on is shown in

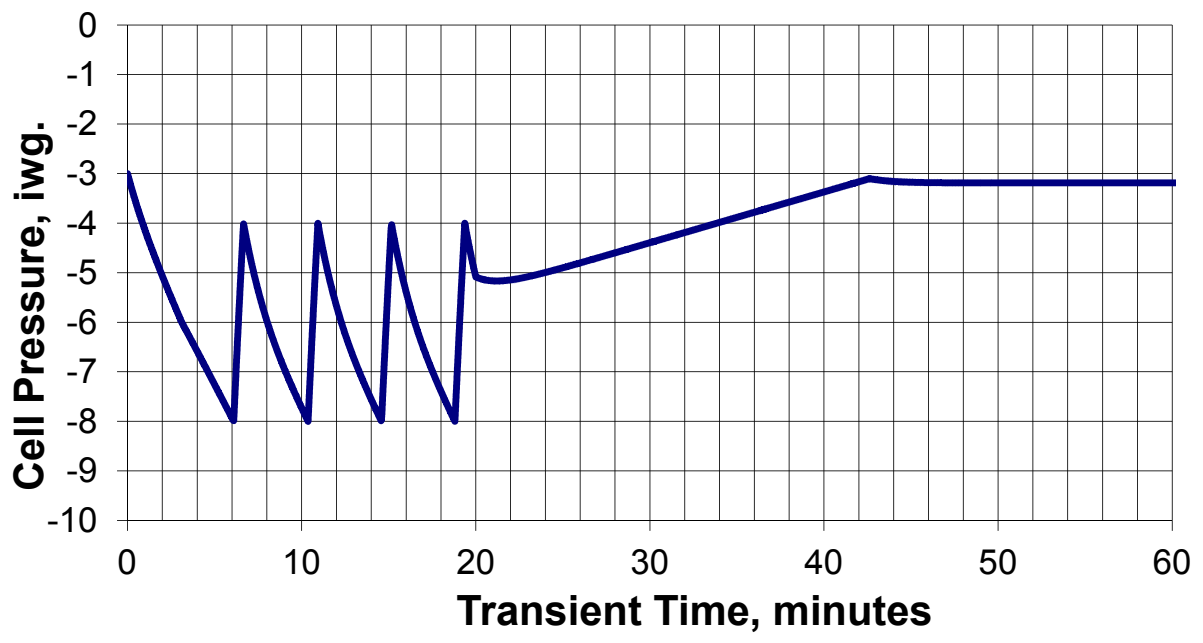

Figure 13 with a reduced $400 \mathrm{cfm}$ flow in the emergency argon system. As with the previous case, the pressure declines to the -6 iwg setpoint of the $18 \mathrm{cfm}$ makeup supply, and it turns, on but the effect on the pressure trace is barely noticeable. The $400 \mathrm{cfm}$ emergency supply turns on at -8 iwg and brings the pressure up to the -4 iwg shut off setpoint but not as quickly as in the previous case. The pressure is brought down again over four minutes to the emergency supply setpoint, and the process repeats until the vacuum pump times out at 20 minutes into the incident. Here the $18 \mathrm{cfm}$ makeup supply continues to bring the pressure up until its shutoff setpoint of -3.1 iwg is reached. Although the emergency argon flow rate in is $400 \mathrm{cfm}$, it only averages $140 \mathrm{cfm}$ to keep up with the $140 \mathrm{cfm}$ vacuum pump flow rate. 
INL/EXT-11-21198

Revision 0

December 2011

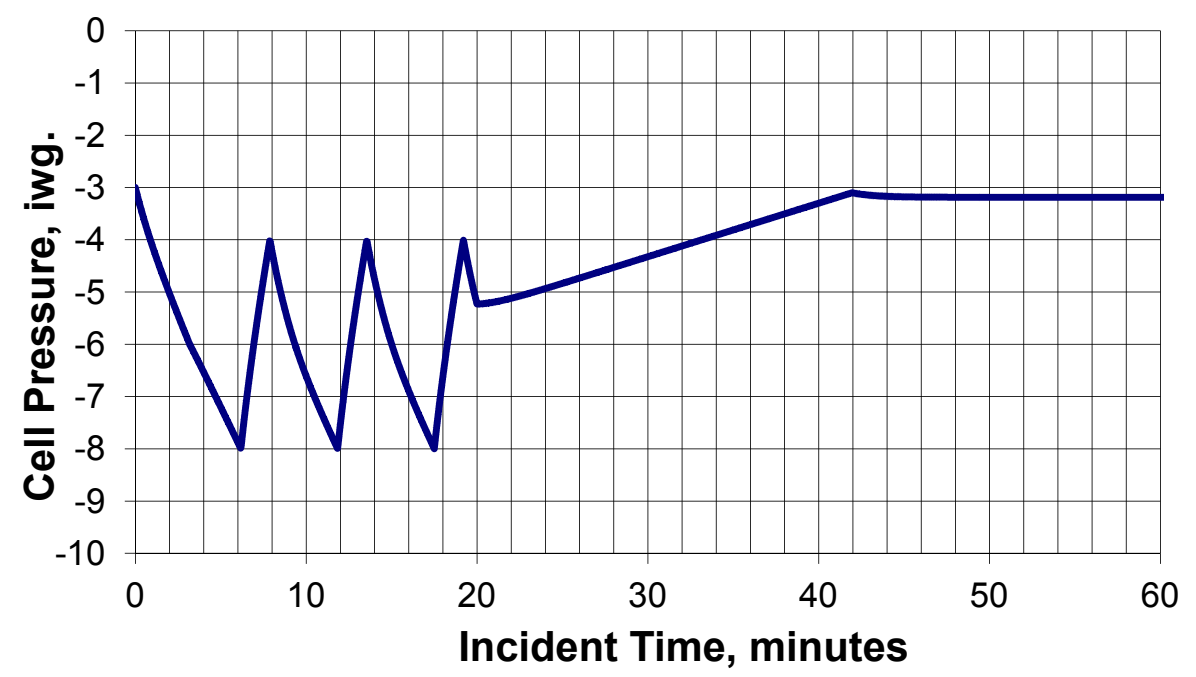

Figure 17. Pressure history (dFCF VacPumpFailsOn B-20 min limit400cfm.xls).

Any emergency argon flow rate at or above $140 \mathrm{cfm}$ will produce nearly the same incident but with less oscillations for the lower emergency flow rates.

\section{Vacuum Pump Fails On - Times out in 20 Minutes - No Emergency Argon}

The pressure history for a140 cfm vacuum pump failing on is shown in

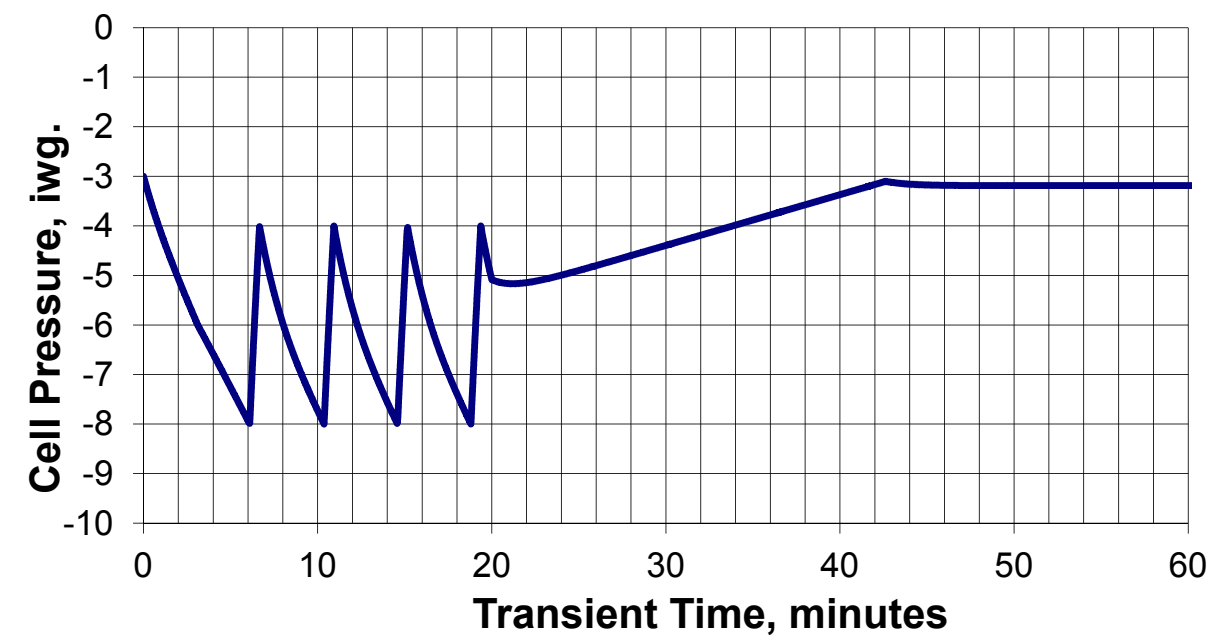

Figure 13 with no emergency argon flow. As with the previous case, the pressure declines to the -6 iwg setpoint of the $18 \mathrm{cfm}$ makeup supply, and it turns, on but the effect on the pressure trace is barely noticeable. The pressure continues on down to $-17 \mathrm{iwg}$, at which time the vacuum pump times out. Then the $18 \mathrm{cfm}$ makeup supply is able to increase pressure until its shutoff setpoint of $-3.1 \mathrm{iwg}$ is reached at 155 minutes. 
INL/EXT-11-21198

Revision 0

December 2011

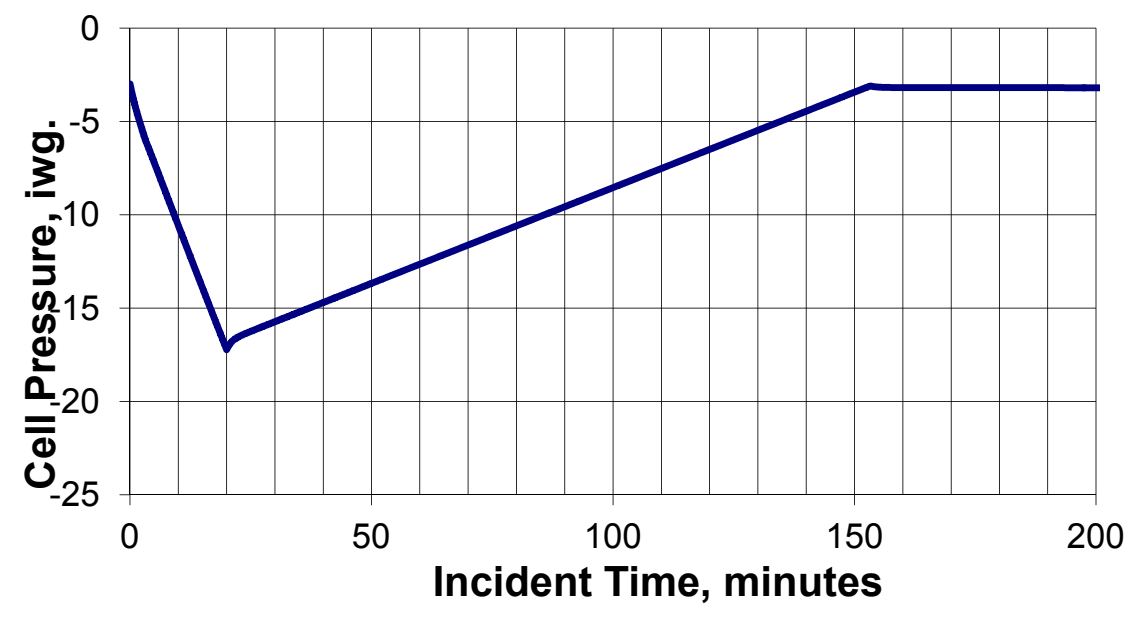

Figure 18. Pressure history - (dFCF VacPumpFailsOn C-20 min limit No emer.xls).

\section{Vacuum Pump Fails On - Time Limit fails - Emergency Argon Available}

The effect of the time out feature failure is investigated in this study. Figure 19 shows the pressure history. As in the first case, the pressure quickly decreases to the makeup argon setpoint, which turns on but continues on down to the emergency supply setpoint which turns on. The pressure then oscillates between the emergency argon on/off setpoints until the emergency supply runs out. Then the pressure decreases to the underpressure relief setpoint. It opens and allows air into the cell. At 150 minutes into the transient, enough air has entered into the cell that combustion of the exposed metal in the cell is predicted to burn.

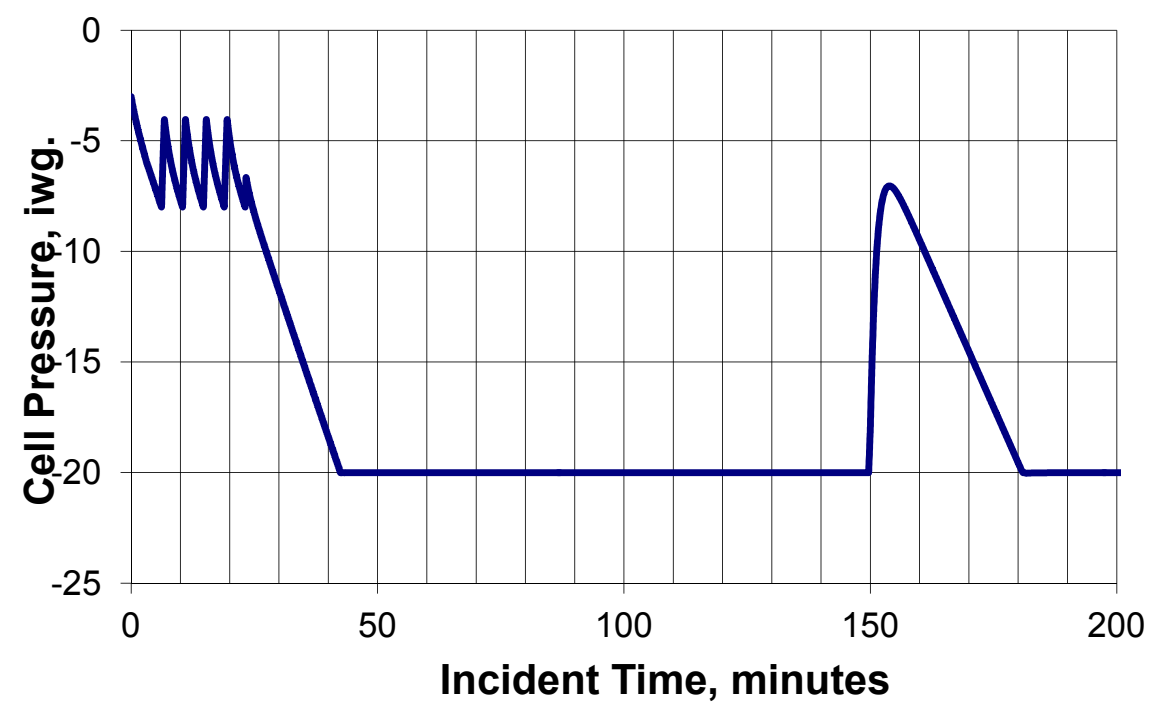

Figure 19. Pressure history (dFCF VacPumpFailsOn D-No time limit.xls). 
INL/EXT-11-21198

Revision 0

December 2011

The cell and liner temperatures are shown in Figure 20. Except for oscillations due to argon inflow and outflow, the temperature remains constant until combustion.

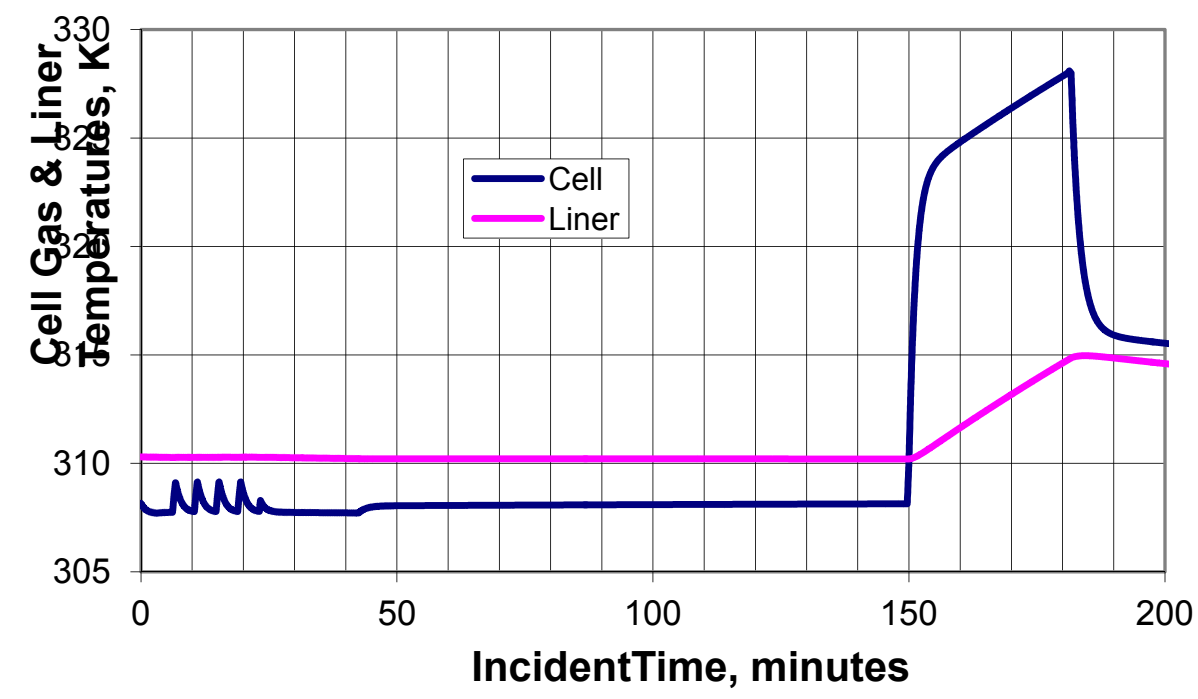

Figure 20. Temperatures (dFCF VacPumpFailsOn D-No time limit.xls).

The flow rates are shown in Figure 21. The early part of the is the same as Case 1 until the underpressure relief opens up. It stays open until combustion occurs. Combustion increases the pressure, shutting the underpressure relief. In spite of the vacuum pump continuing to exhaust $140 \mathrm{cfm}$ from the cell, it stays shut until combustion is complete. Then, the temperature drops and combined with the $140 \mathrm{cfm}$ a large in-surge occurs but then flow quickly settles down to the combustion rate.

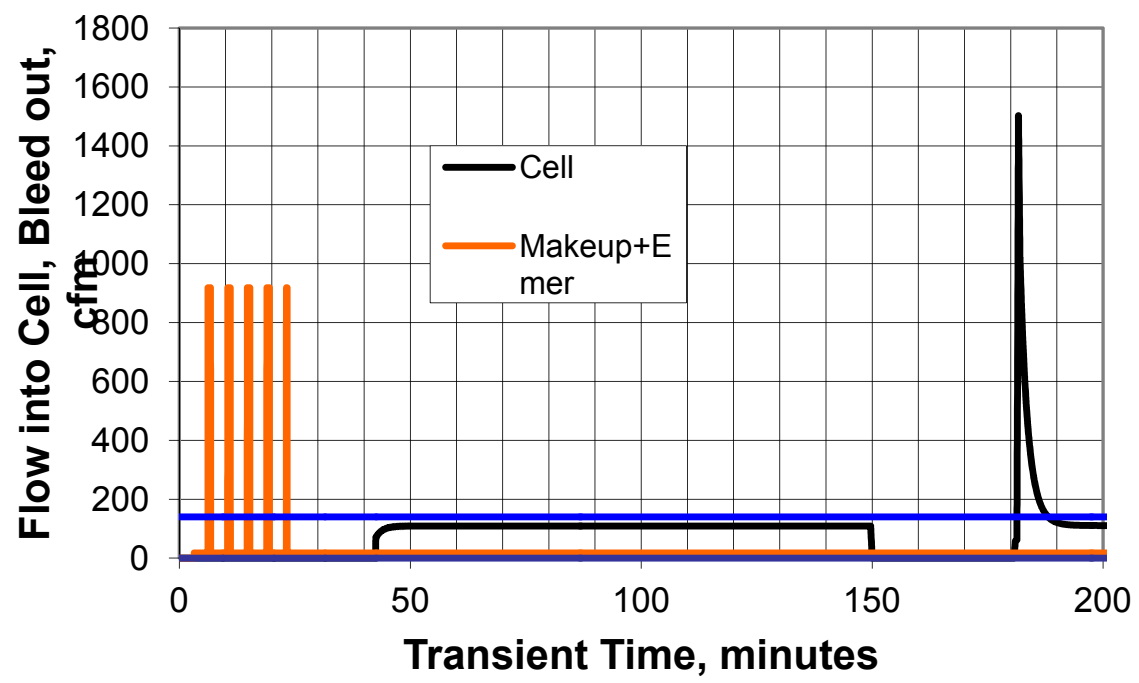

Figure 21. Flow rates (dFCF VacPumpFailsOn D-No time limit.xls).

\section{E. Vacuum Pump Fails On - Time Limit Fails - No Emergency Argon Supply}

In this analysis, the emergency argon supply is assumed to be absent. The pressure history is shown in Figure 22. The pressure decreases quickly to the $-20 \mathrm{iwg}$ underpressure relief setpoint and stays there 
INL/EXT-11-21198

Revision 0

December 2011

until enough air has entered for combustion at 130 minutes. Combustion is 20 minutes earlier than in the previous case.

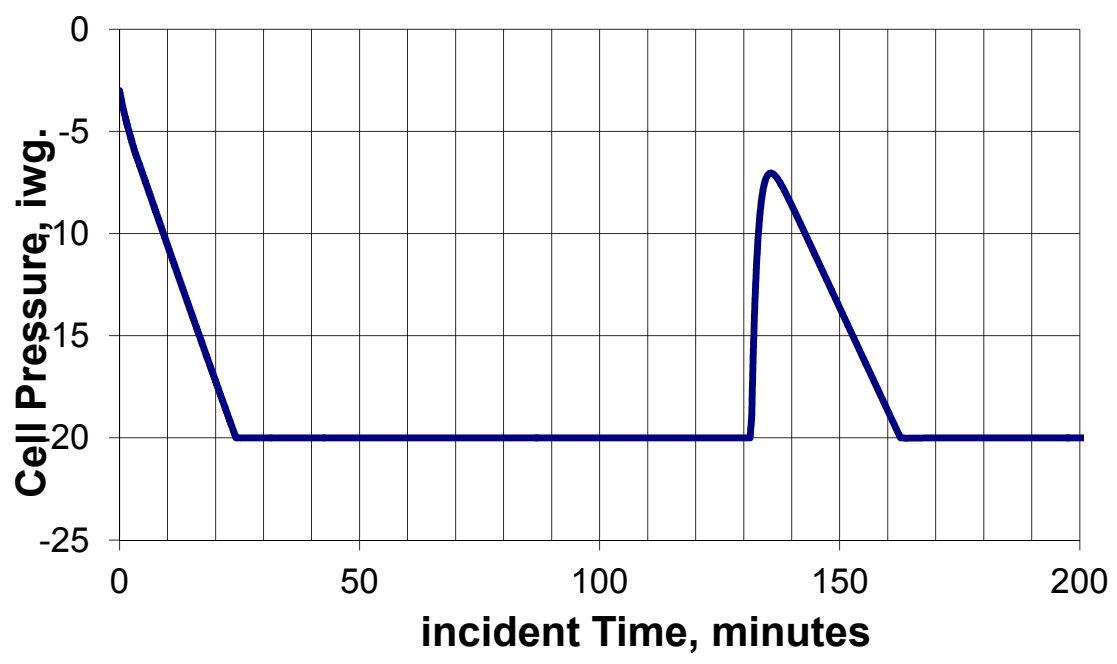

Figure 22. Pressure history (dFCF VacPumpFailsOn E-No time limit NoEmer.xls).

The behavior of the other parameters are the same as in the previous case after combustion occurs, as shown in Figure 23 and Figure 24.

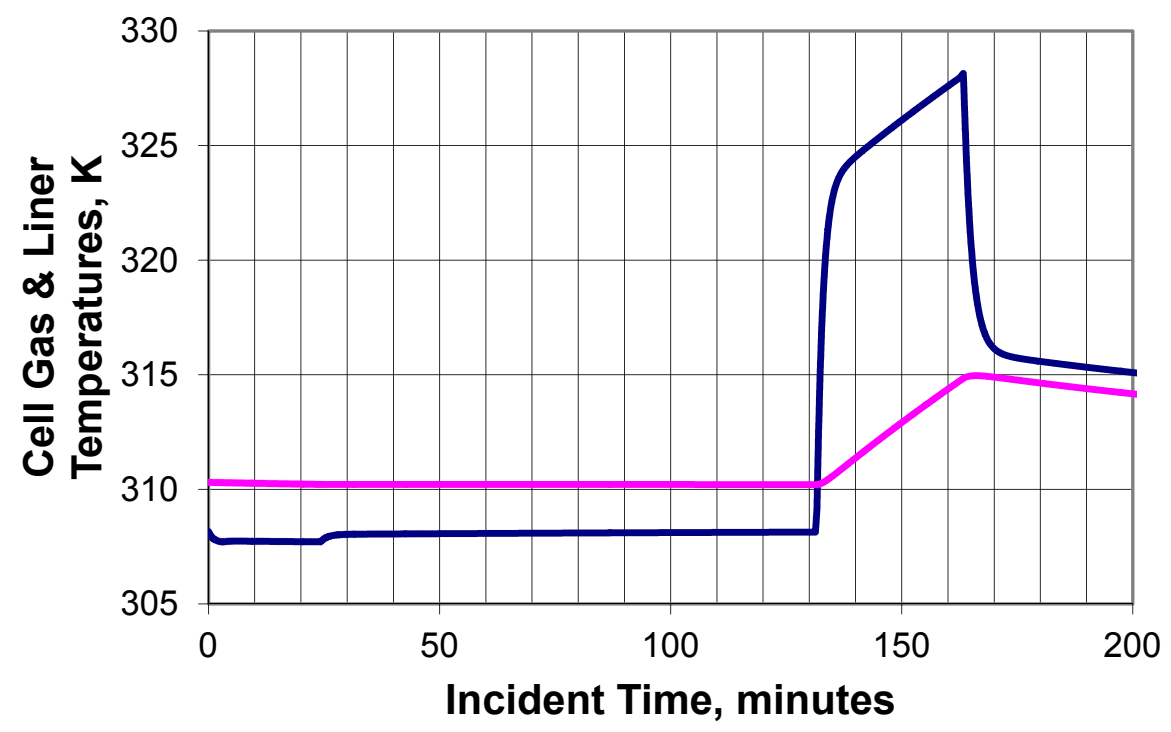

Figure 23. Temperatures (dFCF VacPumpFailsOn E-No time limit NoEmer.xls). 
INL/EXT-11-21198

Revision 0

December 2011

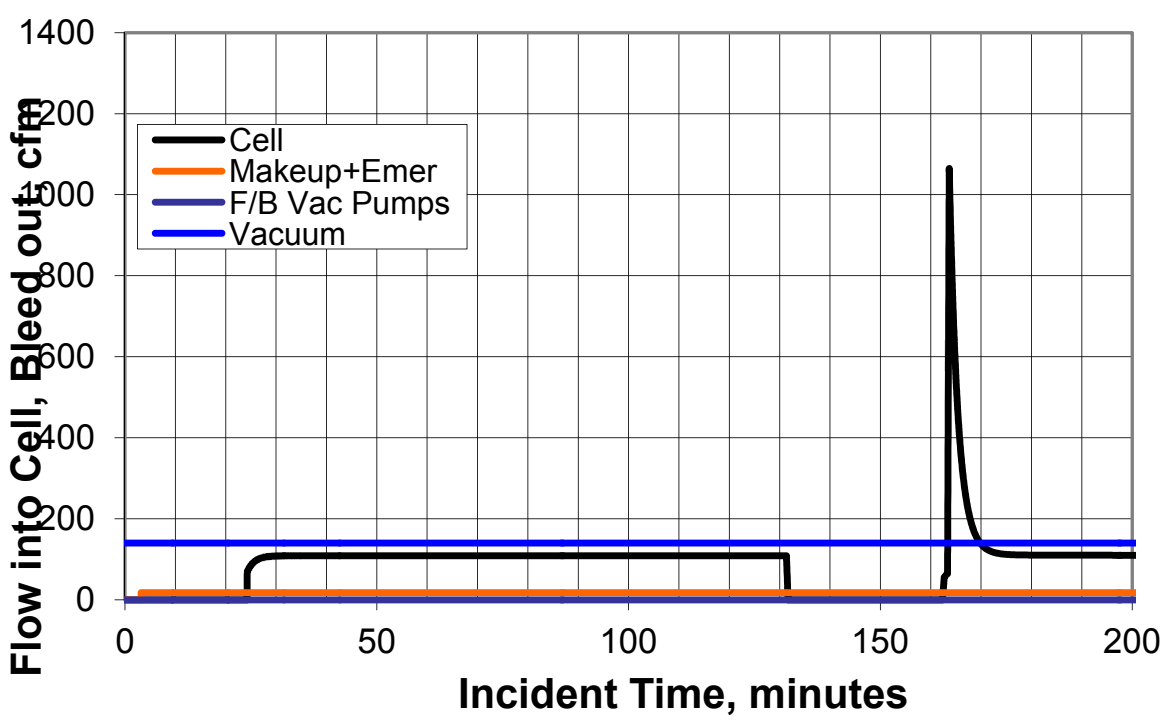

Figure 24. Flow rates (dFCF VacPumpFailsOn E-No time limit NoEmer.xls).

Note that in both the last two cases, the makeup argon supply remains on and will remain on unless an interlock shuts it off or it runs out since the vacuum pump will continue to remove cell atmosphere and draw outside air into the cell. The cell will eventually become full of air, as is shown in Figure 25, where the argon will reduce to zero mass, and the air will increase to $1,605 \mathrm{~kg}$. The difference in mass between a cell full of argon and one full of air is due to the difference in molecular weights.

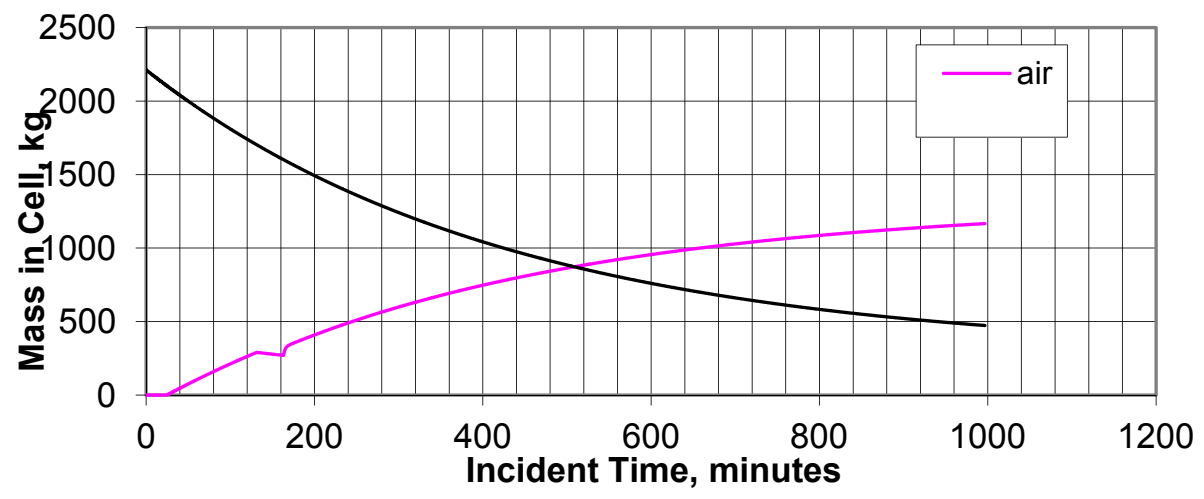

Figure 25. Mass (dFCF VacPumpFailsOn E-No time limit NoEmer.xls).

\section{F. Conclusions for Vacuum Pump Failing On}

The failing on of a vacuum pump causes very little disruption to the cell performance if the time limit on the pump works and the emergency argon is available. If the emergency argon is not available but the time out feature works, the pressure does not reach the underpressure relief setpoint, so no air is admitted to the cell. If the time out feature has been removed or does not work, then the pressure will decrease to the underpressure relief setpoint, and combustion is predicted. If emergency argon is available, then combustion can be avoided if the operator turns off the vacuum pump within 150 minutes. If it is not available, then the operator still has over two hours (130 minutes) to avoid combustion. 
INL/EXT-11-21198

Revision 0

December 2011

\section{ARGON SUPPLIES FAILING ON}

In this section, the argon supplies failing on incident has been investigated. In the first case, both the emergency argon and the makeup argon are assumed to fail on. In the second case, the emergency argon is assumed absent, and the makeup argon is assumed to fail on.

\section{A. Emergency and Makeup Argon Fail On}

The pressure is shown in Figure 26. The pressure quickly increases to the safety exhaust system (SES) setpoint and then is brought down by the SES fan. The pressure decreases slowly until the argon emergency system empties. Then the pressure decreases at a faster rate until the pump reaches its shutoff head. Once the SES system is activated under normal conditions, the emergency and makeup argon systems would be disabled; however, this is a case of multiple system failures.

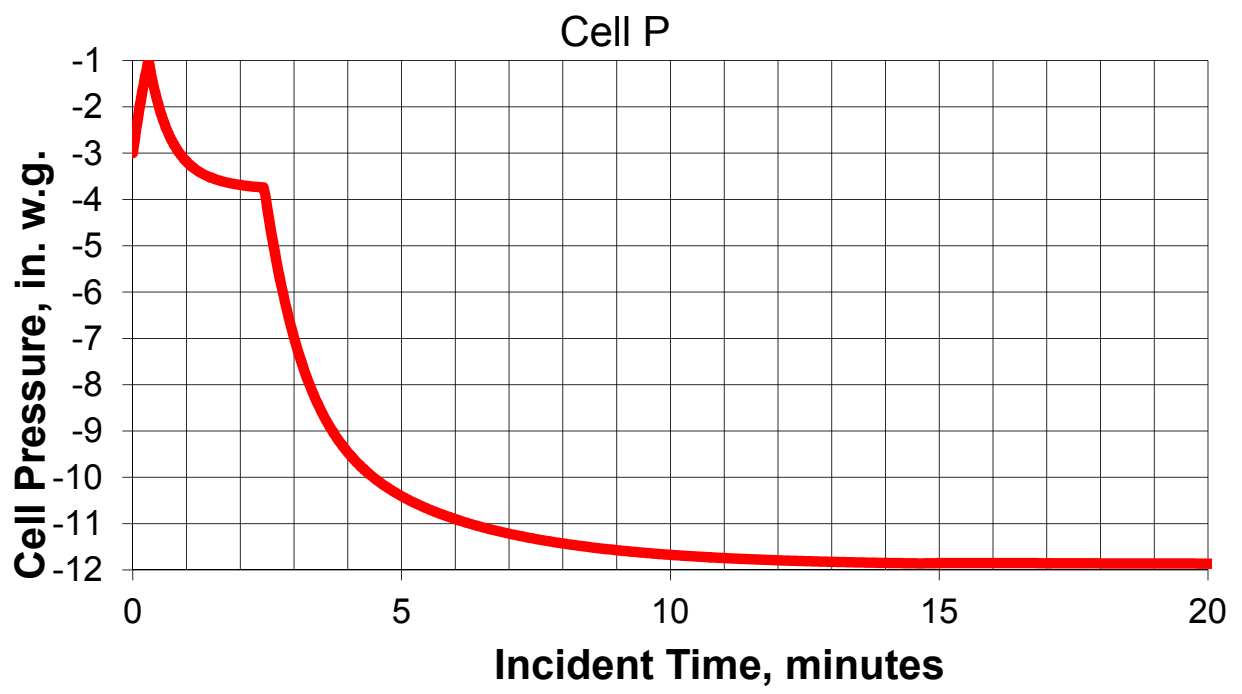

Figure 26. Pressure (gAMkup+EmerOnCont.xlsm).

The temperature is shown in Figure 27. The temperature is responding initially to the pressure fluctuations and later on to the refrigeration under P-PID control. The P-PID control is attempting to bring the pressure back to the operating pressure. It eventually drives the refrigeration to zero in attempting to raise the temperature. Then the heat generation in the cell causes the temperature to increase. 
INL/EXT-11-21198

Revision 0

December 2011

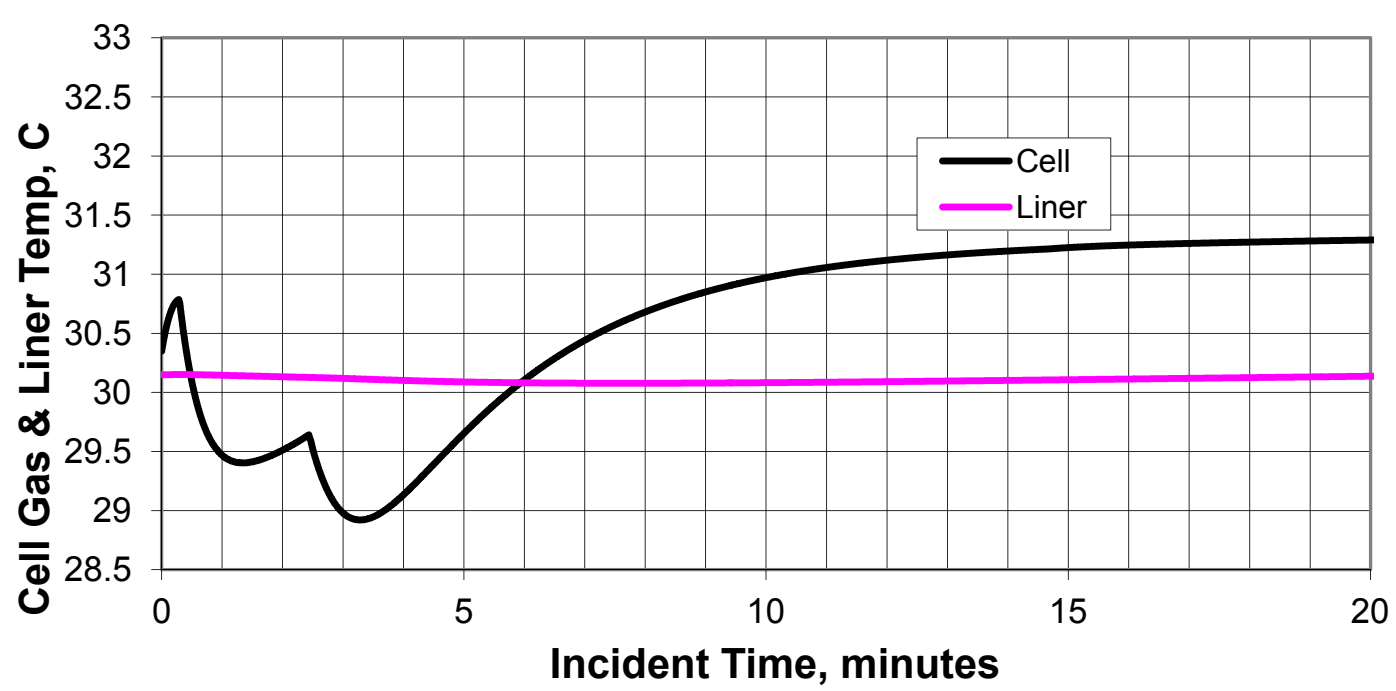

Figure 27. Temperature (gAMkup+EmerOnCont.xlsm).

The flow rates are shown in Figure 28. The emergency argon is empty after 2.5 minutes. The pressure drops much faster after the emergency supply empties.

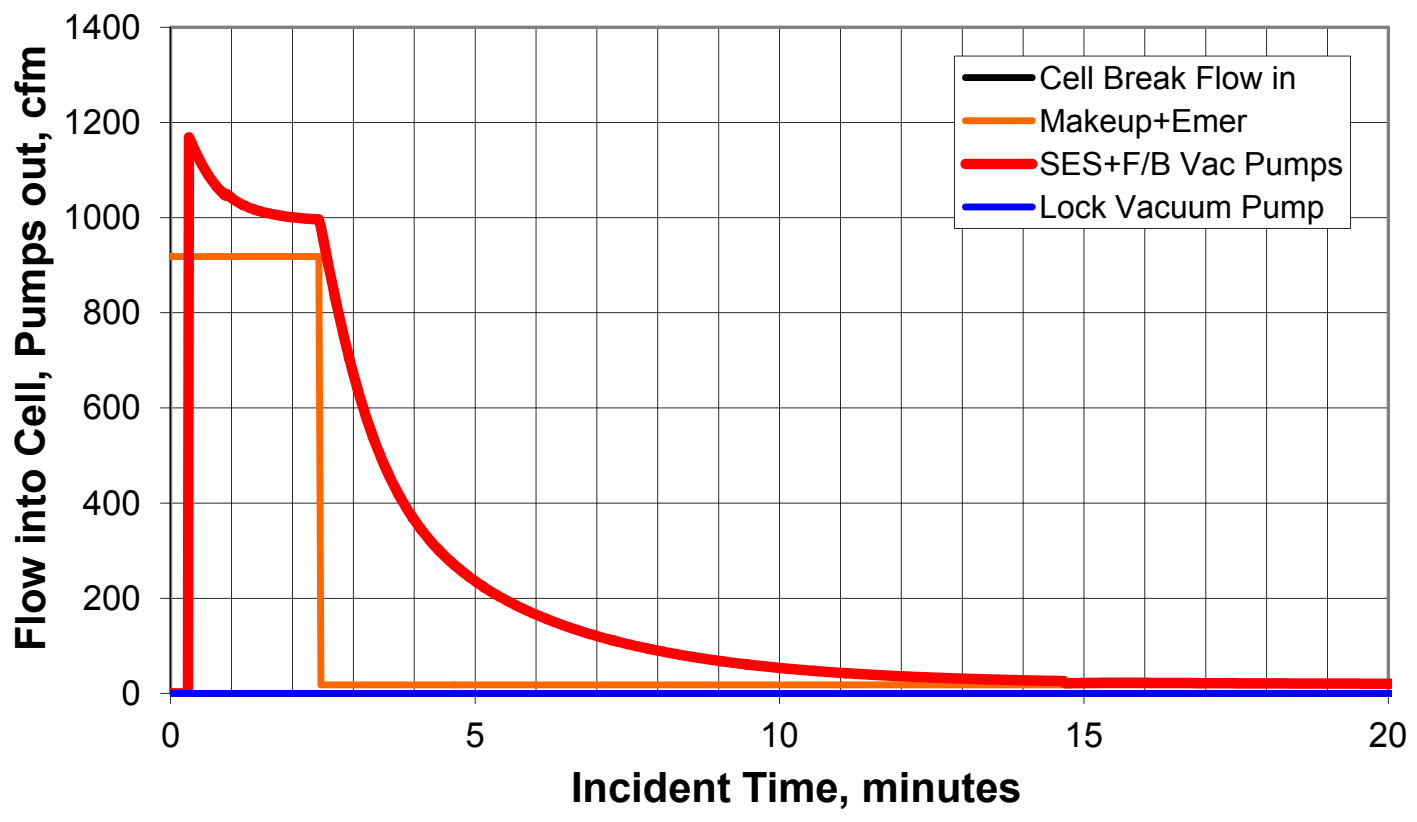

Figure 28. Flow rates (gAMkup+EmerOnCont.xlsm).

The flow drops quickly as the pressure drops in the cell since the SES fan (normally only one fan will be running, but both fans may run if the initial flow rate from the first fan is abnormally low) cannot remove more gas after the fan shutoff head of -12 iwg is reached. The SES fan, however, will continue to remove the makeup argon supply as well as cell gas expansion due to the temperature increase. 
INL/EXT-11-21198

Revision 0

December 2011

\section{B. Emergency Argon not Available, Makeup Argon Fails On}

Three sub cases were analyzed. The first assumes that the F/B vacuum pumps supply $16 \mathrm{cfm}$ at full output. The second case assumes the F/B vacuum pumping system has been modified so it can supply 20 $\mathrm{cfm}$. The third run assumed the proportional integral derivatives (PIDs) are not working.

F/B Vacuum Pumps at 16 cfm: The pressure for the first subcase is shown in Figure 29 (linear) for a short time and Figure 30 (semilog in time). The pressure does not change much.

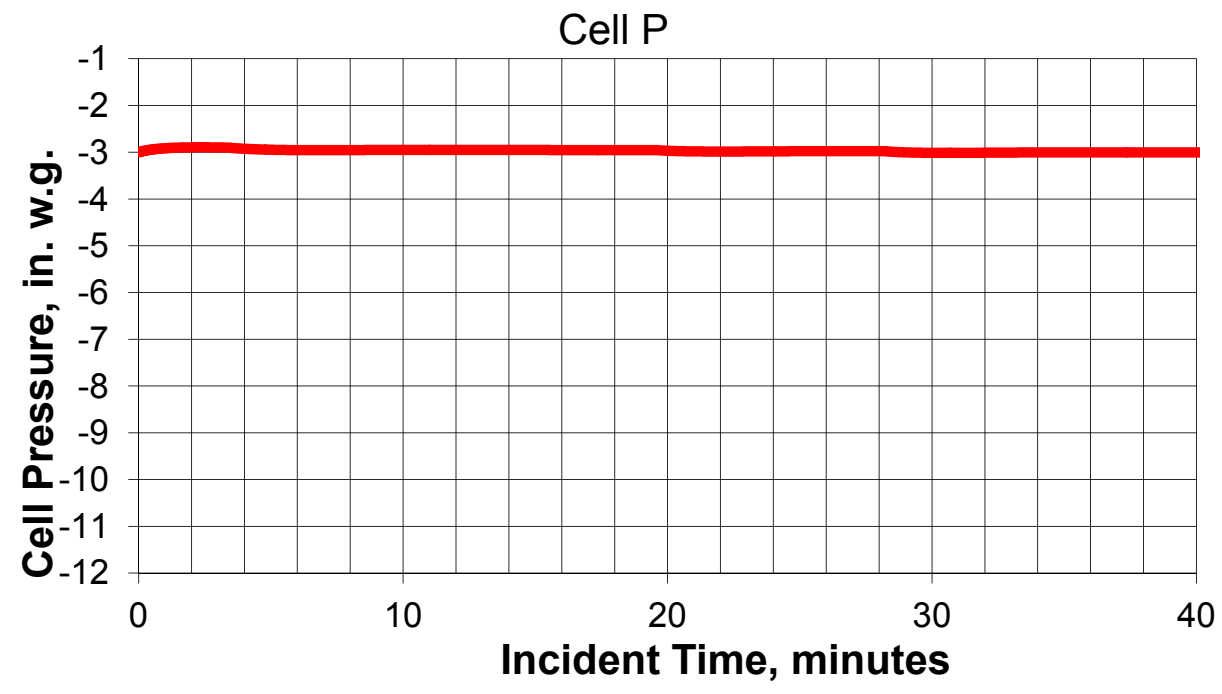

Figure 29. Pressure (gB1MkupNoEmerCont16cfm.xlsm).

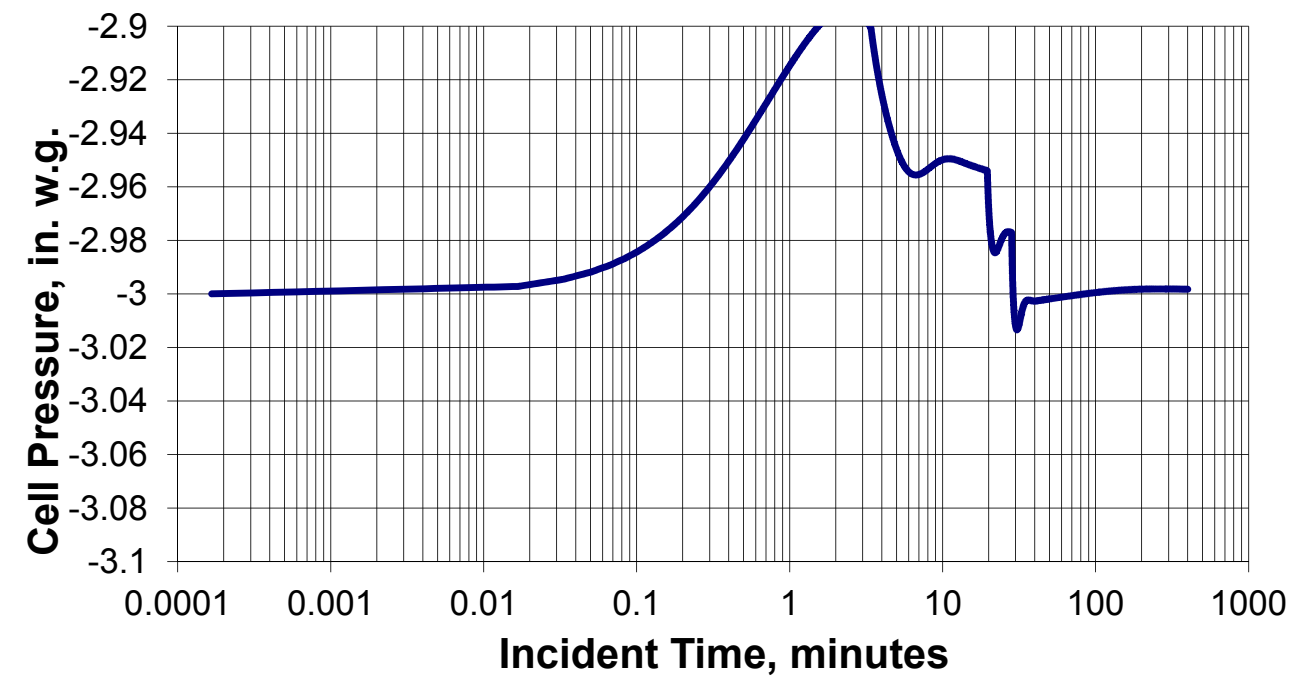

Figure 30. Pressure (gB1 MkupNoEmerCont16cfm.xlsm). 
INL/EXT-11-21198

Revision 0

December 2011

The temperature is shown in Figure 31. The temperature first increases a small amount, and because it does, the control system increases the cooling to decrease the pressure by decreasing the temperature.

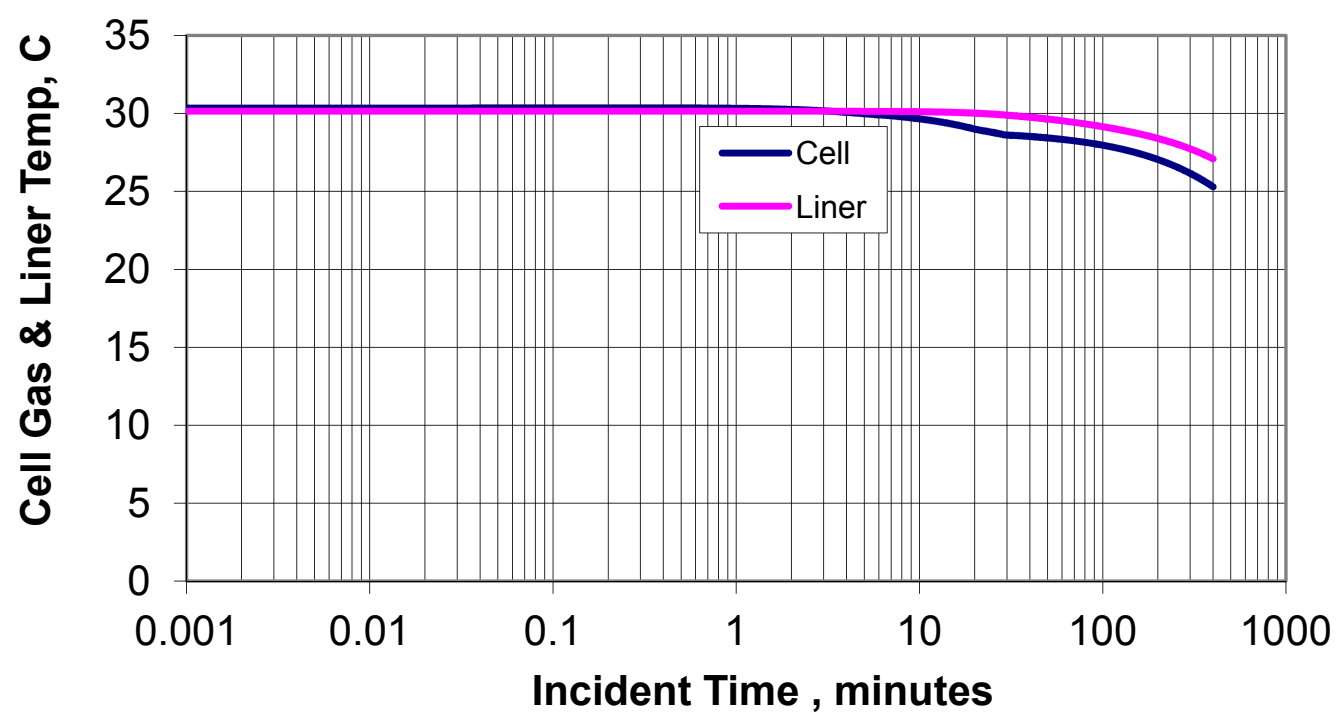

Figure 31. Temperature (gB1MkupNoEmerCont16cfm.xlsm).

The flow rate of the makeup argon and the F/B vacuum pumps is shown in Figure 32. The F/B vacuum pumps come on when the temperature goes below the setpoint temperature. The vacuum pumps stay on, as does the makeup argon supply, so the net result is a small continual input of $2 \mathrm{cfm}$ to the cell. The cooling increases enough to keep the pressure constant.

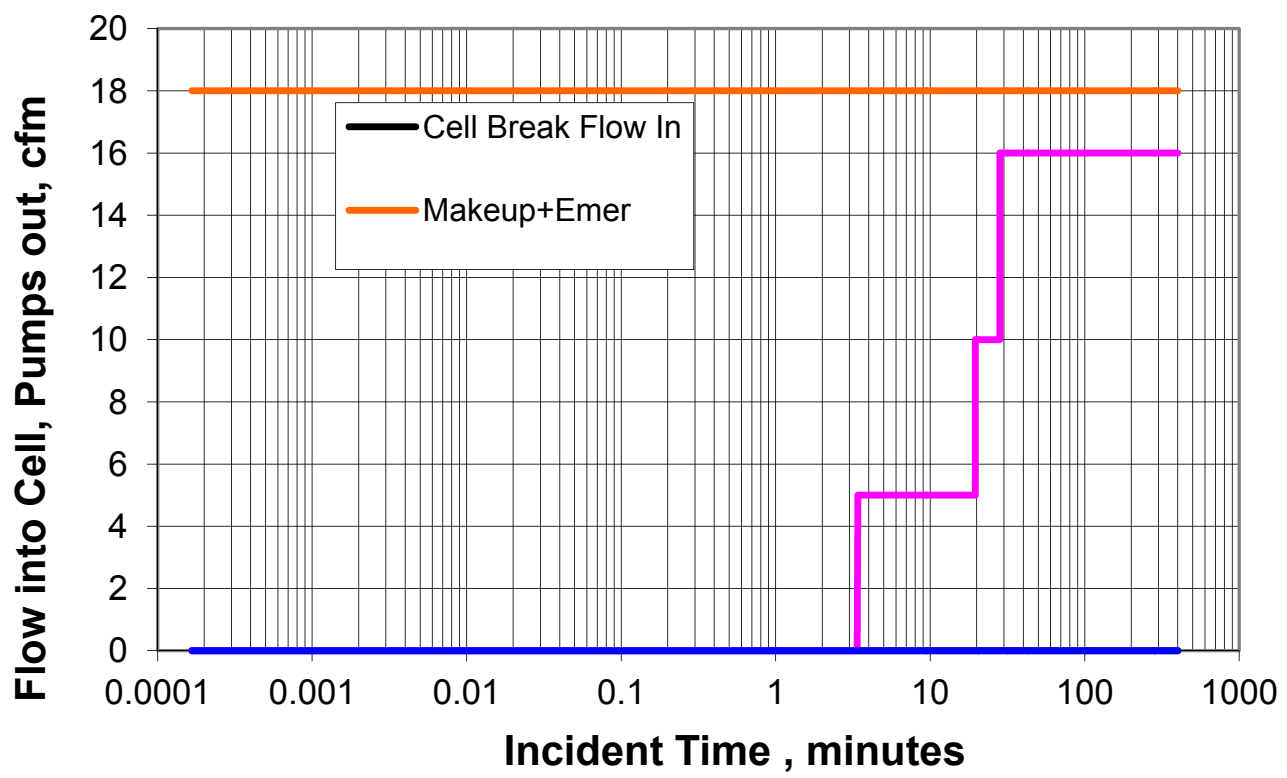

Figure 32. Flow rate (gB1MkupNoEmerCont16cfm.xlsm). 
INL/EXT-11-21198

Revision 0

December 2011

In this case, the $\mathrm{F} / \mathrm{B}$ vacuum pumps have been assumed to run at $16 \mathrm{cfm}$ at maximum output. The cell is almost at steady state since the net input to the cell will remain at $2 \mathrm{cfm}$. The temperature will continue to decrease until the operators stop the transient or the refrigeration peaks out due to low cell pressure.

F/B Vacuum Pumps at $20 \mathrm{cfm}$ : If the pumping system has been reworked, the pumps should have a maximum output of $20 \mathrm{cfm}$. This case does not reach a steady state but reaches instead an oscillatory one. The flow rate trace corresponding to this case is shown in Figure 33. It has been run out to 1,000 minutes ( 16.6 hours), and it shows that the net flow after the all the pumps come on is $-2 \mathrm{cfm}$. This causes the flow rate of $\mathrm{F} / \mathrm{B}$ vacuum pumps to decrease until the cell mass becomes too large again. This happens twice during this long transient.

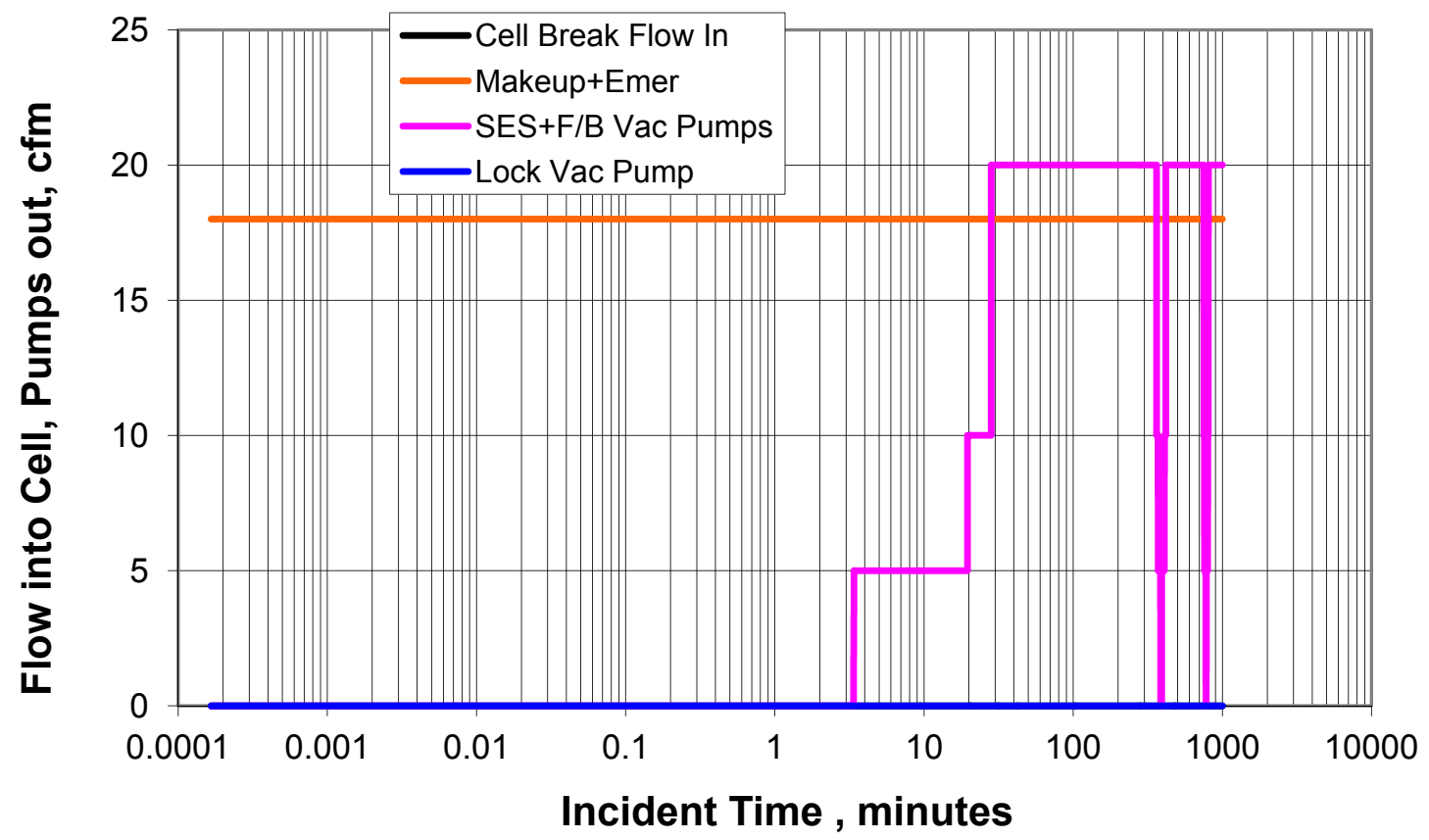

Figure 33. Flow rate (gB2MkupNoEmerCont20cfm.xlsm).

The pressure is shown in Figure 34. It oscillates when the vacuum pumps shut off and turn back on. The oscillation is so small that the pressure is almost constant. 
INL/EXT-11-21198

Revision 0

December 2011

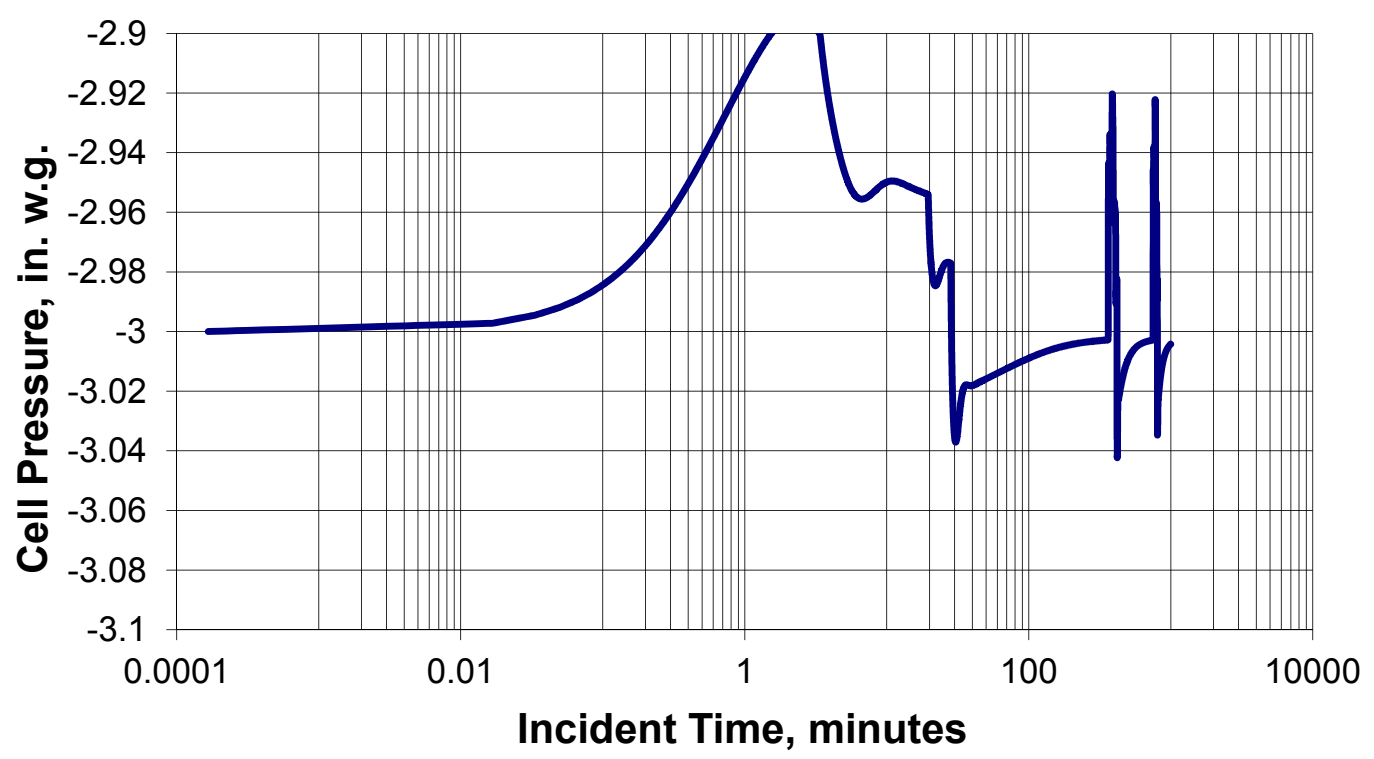

Figure 34. Pressure Versus Log of Time (gB2MkupNoEmerCont20cfm.xlsm).

T-PID Not Working: Both of the above cases were run assuming that the P-PID is working. In the following case, the P-PID is assumed to not work, but the T-PID is working. The pressure trace is shown in Figure 35. The makeup argon causes the pressure to rise to the SES setpoint in 19 minutes. Since the P-PID is not working, the temperature of the gas in the cell increases due to the mass addition. The F/B vacuum pumps never come on because the temperature never decreases below the temperature setpoint.

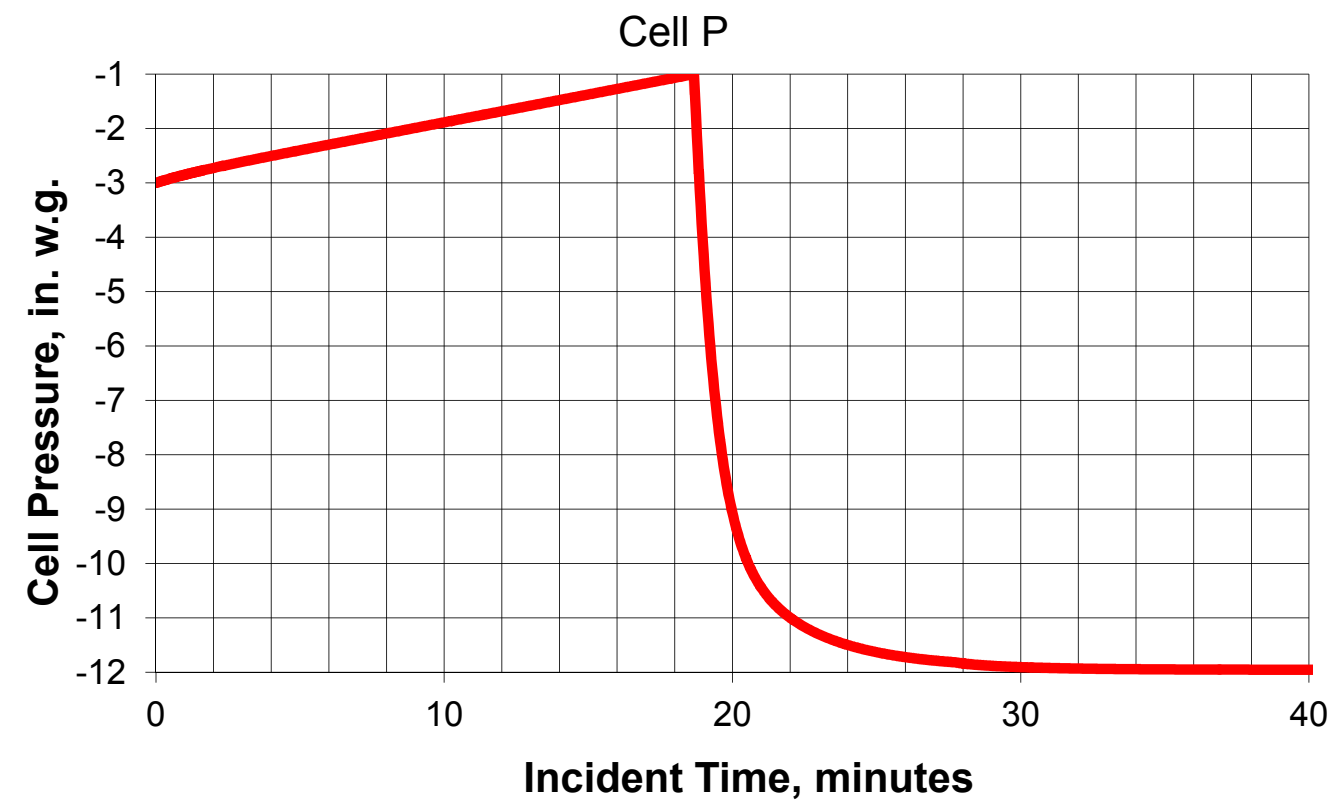

Figure 35.Pressure Versus Linear Time (gB3MkupOn NoEmerNoCont.xlsm). 
INL/EXT-11-21198

Revision 0

December 2011

Operations can recover from this incident once the makeup argon supply is turned off. This is an inicident encountered during testing the SES system since when the SES system is tested power is automatically turned off to the solenoid valves that allow the makeup argon supply to add argon to the argon cell.

\section{Conclusions of Failed on Argon Supplies}

It is clear that it would be better not to have an emergency argon supply for the argon failing on incident. If there is only a makeup argon supply, if it fails on, the control system will be able to keep cell pressure almost constant because the cell temperature will rise, which will cause the F/B vacuum pumps to come on to bring the pressure back down. If the control system fails or is not on during this transient, then the SES would be activated and bring the cell pressure down to $-12 \mathrm{iwg}$. Operations can bring the cell back to normal conditions from this transient since it is a normal condition encountered annually when the SES system is tested.

\section{CONCLUSIONS}

The cell cooling failing on incident reduces the cell pressure and temperature. Even the largest excess cooling rate does not cause the under pressure relief to open. Even without the emergency argon, the pressure only decreased to $-17 \mathrm{iwg}$, and the makeup argon and covergas would eventually be able to bring the pressure back up to oscillate in the -3.1 to -6 iwg range until the operators repaired the cooling system. Therefore, the emergency argon is not necessary to resolve this incident.

The failing on of a lock vacuum pump with the inner lock door to the cell open causes very little disruption to the cell performance if the time limit on the pump works and the emergency argon is available. If the emergency argon is not available but the time out feature works, the pressure does not reach the underpressure relief setpoint, so no air is admitted to the cell. If the time out feature has been removed or does not work (the latter being a case of multiple failures, which is not credible), then the pressure will decrease to the underpressure relief setpoint and admit air to the cell. Continued operation of the pump would bring in enough air to cause combustion of the exposed metal fuel. If emergency argon is available, then combustion can be avoided if the operator turns off the vacuum pump within 150 minutes. If it is not available, then the operator still has over two hours (130 minutes) to avoid combustion.

In the argon supply failing on incident, it is obviously better to not have an emergency argon system that could fail on. If there is only a makeup argon supply, if it fails on, the control system will be able to keep cell pressure almost constant because the cell temperature will rise which will cause the $\mathrm{F} / \mathrm{B}$ vacuum pumps to come on to bring the pressure back down. If the control system fails or is not on, then the SES would be activated and bring the cell pressure down to -12 iwg. Operations can bring the cell back to normal conditions from this incident since it is a normal condition encountered annually when the SES system is tested. 